University of New Hampshire

University of New Hampshire Scholars' Repository

Faculty Publications

$1-1-1995$

\title{
Modeling physical and chemical climate of the northeastern United States for a geographic information system
}

\author{
Scott V. Ollinger \\ University of New Hampshire, Durham, scott.ollinger@unh.edu \\ John D. Aber \\ University of New Hampshire, Durham, john.aber@unh.edu \\ Anthony C. Federer \\ USDA Forest Service
}

Gary M. Lovett

Jennifer M. Ellis

Follow this and additional works at: https://scholars.unh.edu/faculty_pubs

\section{Recommended Citation}

Ollinger, S.V., J.D. Aber, C.A. Federer, G.M. Lovett, and J.M. Ellis. 1995. Modeling physical and chemical climate of the northeastern U.S. for a geographic information system. USDA Forest Service GTR NE-191.

This Report is brought to you for free and open access by University of New Hampshire Scholars' Repository. It has been accepted for inclusion in Faculty Publications by an authorized administrator of University of New Hampshire Scholars' Repository. For more information, please contact Scholarly.Communication@unh.edu. 
United States

Department of

Agriculture

Forest Service

Northeastern Forest

Experiment Station

General Technical

Report NE-191

近的

\section{Modeling Physical and Chemical Climate of the Northeastern United States for a Geographic Information System}

Scott V. Ollinger John D. Aber

C. Anthony Federer

Gary M. Lovett Jennifer M. Ellis

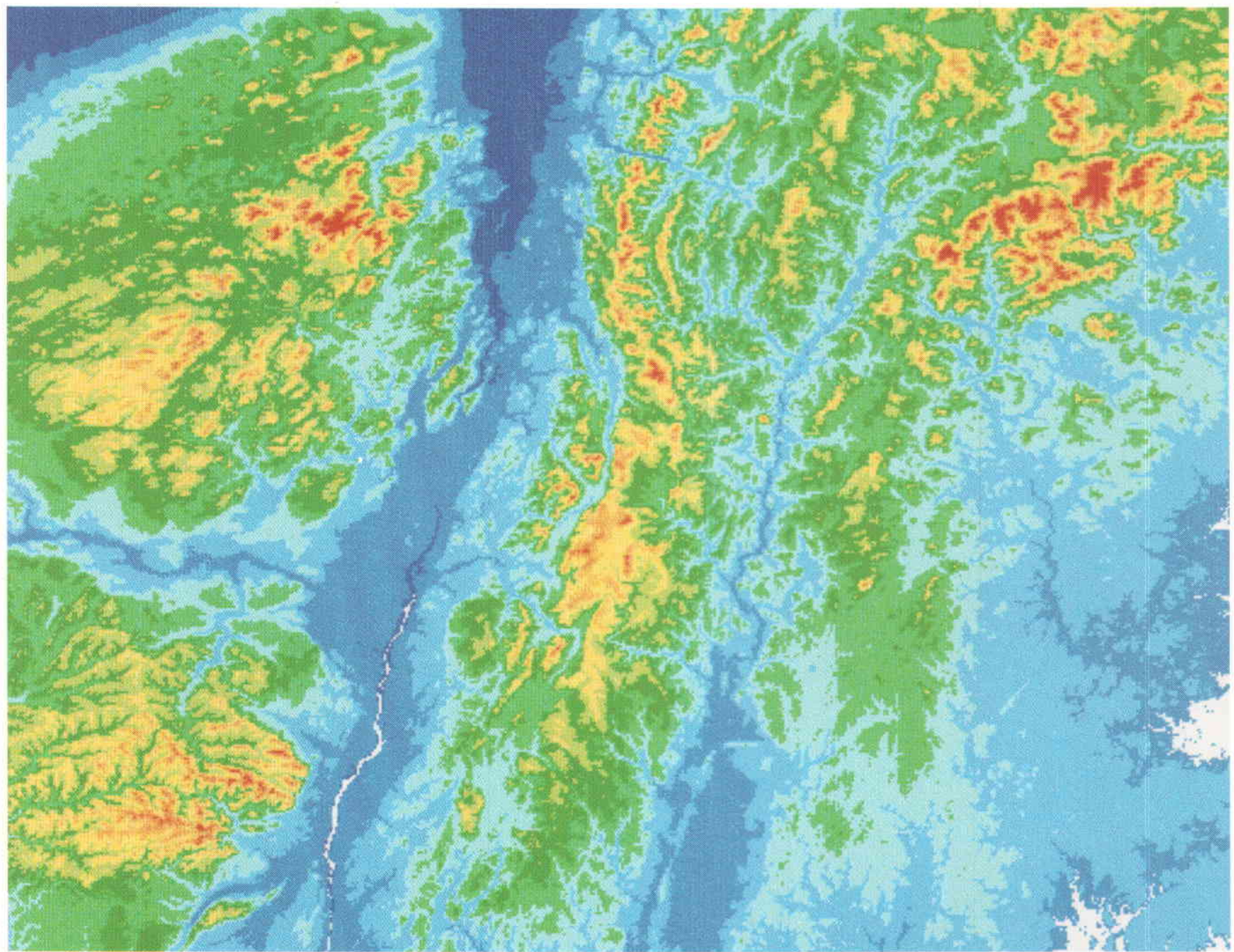




\begin{abstract}
A simple model of physical and chemical climate for the northeastern United States (New York and New England) that can be incorporated into a geographic information system (GIS) for integration with ecosystem models is presented. The variables include average maximum and minimum daily temperature, precipitation, humidity, and solar radiation, all at a monthly time step, as well as annual wet and dry deposition of sulfur and nitrogen. Regressions on latitude, longitude, and elevation are fitted to regional data bases of these variables. The equations are combined with a digital elevation model (DEM) of the region to generate GIS coverages of each variable.
\end{abstract}

\title{
The Authors
}

SCOTT V. OLLINGER, JOHN D. ABER, and JENNIFER M. ELLIS are with Complex Systems Research Center, Institute for the Study of Earth, Oceans, and Space, University of New Hampshire, Durham, New Hampshire.

C. ANTHONY FEDERER is with the Northeastern Forest Experiment Station, Durham, New Hampshire.

GARY M. LOVETT is with the Institute of Ecosystem Studies, Millbrook, New York.

\section{Acknowledgments}

We gratefully acknowledge the help of Rick Lathrop for providing the digital elevation map of the study region and John Bognar for helping with the GIS data processing. We thank Robert Adams for help in acquiring and interpreting climate data, and Lloyd Swift and Lawrence Dingman for comments on the manuscript. This research is a contribution to the Global Change Program of the USDA Forest Service and to the program of the Institute of Ecosystem Studies.

Manuscript received for publication 29 October 1993

USDA FOREST SERVICE

5 RADNOR CORP CTR STE 200

PO BOX 6775

RADNOR PA 19087-8775

February 1995 


\section{Introduction}

Increased understanding of how ecosystems function has allowed scientists to build predictive models that can address the effects of disturbances such as atmospheric deposition and climate change (Aber and Federer 1992; Rastetter et al. 1991; Pastor and Post 1986). Although intensive, plot-level research is necessary for developing this understanding, the environmental factors that drive ecosystems (and ecosystem models) can change considerably across a region. Thus, it is not possible to make accurate assessments across large areas simply by extrapolating site-specific model predictions.

One approach for making regional projections is to combine ecosystem models with regional-scale data bases of driving variables within a geographic information system (Burke et al. 1990; Aber et al. 1993). In the northeastern United States such an approach is being carried out using models like PnET, a monthly time-step model of photosynthesis, evapotranspiration, and net primary production of forest ecosystems (Aber and Federer 1992).

A crucial part of such an integration is obtaining regional-scale data sets of the input variables required to run the model. The PnET model requires average maximum and minimum daily temperature, precipitation, and solar radiation at a monthly time step, as well as soil-water holding capacity and several vegetation parameters. Similar data are required to run other regional productivity models (for example, Rastetter et al. 1991). The incorporation of atmospheric deposition effects on regional biogeochemistry makes chemical inputs an additional data requirement.

The required soil and vegetation coverages can be derived from existing digital land-cover and soil maps, available from the United States Geological Survey and the United States Department of Agriculture, Soil Conservation Service (USGS 1986, USDA 1991) or from remotely-sensed data. However, the remaining physical-chemical climatic variables are not available readily in digital form, and must be derived from existing data bases in conjunction with digital elevation models. The purpose of this report is to present simple methods for describing the spatial variation of physical and chemical climatic variables across the northeastern United States (New York and New England) that can be incorporated easily into a GIS for integration with ecosystem models. The variables included are maximum and minimum daily temperature, humidity, solar radiation, precipitation, and atmospheric deposition. Atmospheric deposition has been discussed in more detail in a previous paper (Ollinger et al. 1993).

Two common techniques for modeling the spatial variation of climate variables are to: 1) use interpolation algorithms to produce surfaces contoured to fit existing weather station data, and 2) use regression analyses to generate equations relating variation in climate with spatial variables such as geographic position and elevation. The first method offers the advantage of capturing local variability within the data, but is limited by the degree to which data collection stations capture spatial variability across landscapes. This can presend difficulties in landscapes where climate variation is caused largely by complex topography. The second method cannot account easily for variation caused by local factors, but is useful for quantifying spatial trends and applying them across real landscapes.

Another factor to be considered is the ease with which these methods can be incorporated into ecological modeling exercises. The results of interpolation techniques must be stored in digital form and called up as model input when needed. Regression methods summarize spatial trends with simple equations, which allows climate drivers to be generated as ecosystem models run without having to store individual maps of all required variables. This can be important in spatial modeling exercises where many input variables are required across large areas.

In the northeastern United States, important spatial trends in the variables considered occur on two scales: 1) broad-scale patterns that occur across the entire region and 2) local-scale patterns that result from topographic effects. Although localscale variation caused by other factors also is expected (smallscale circulation patterns, proximity to large water bodies), we seek here to explain those trends that exert the greatest influence in large-scale modeling exercises.

In this report, we use multiple regression methods, where possible, to account for climatic variation that occurs across the region and with elevation. Patterns of residuals have been examined to ensure selection of the appropriate models and to identify factors other than regional and elevational trends. Digital coverages of each variable were generated by combining the appropriate equations with an altitude-matrix digital elevation model (DEM) covering eastern New York and New England with 30-arc-second (approximately $0.8 \mathrm{~km}$ ) resolution (USGS 1987). All calculations were performed externally to the GIS and then imported into Arc/Info's ${ }^{1}$ GRID submodule for display (ESRI 1992).

\section{Temperature}

Data used to perform regional analyses of maximum and minimum daily temperature were obtained from 164 weather stations across New York and New England. At each station, daily maximum temperature and daily minimum temperature have been recorded and averaged by month. The values used for this report are 30-year means of these monthly averages, taken from the period of 1951 to 1980 (NOAA 1982). The stations were evenly distributed across the region and range

1The use of trade, firm, or corporation names in this publication is for the information and convenience of the reader. Such use does not constitute an official endorsement or approval by the U.S. Department of Agriculture or the Forest Service of any product or service to the exclusion of others that may be suitable. 


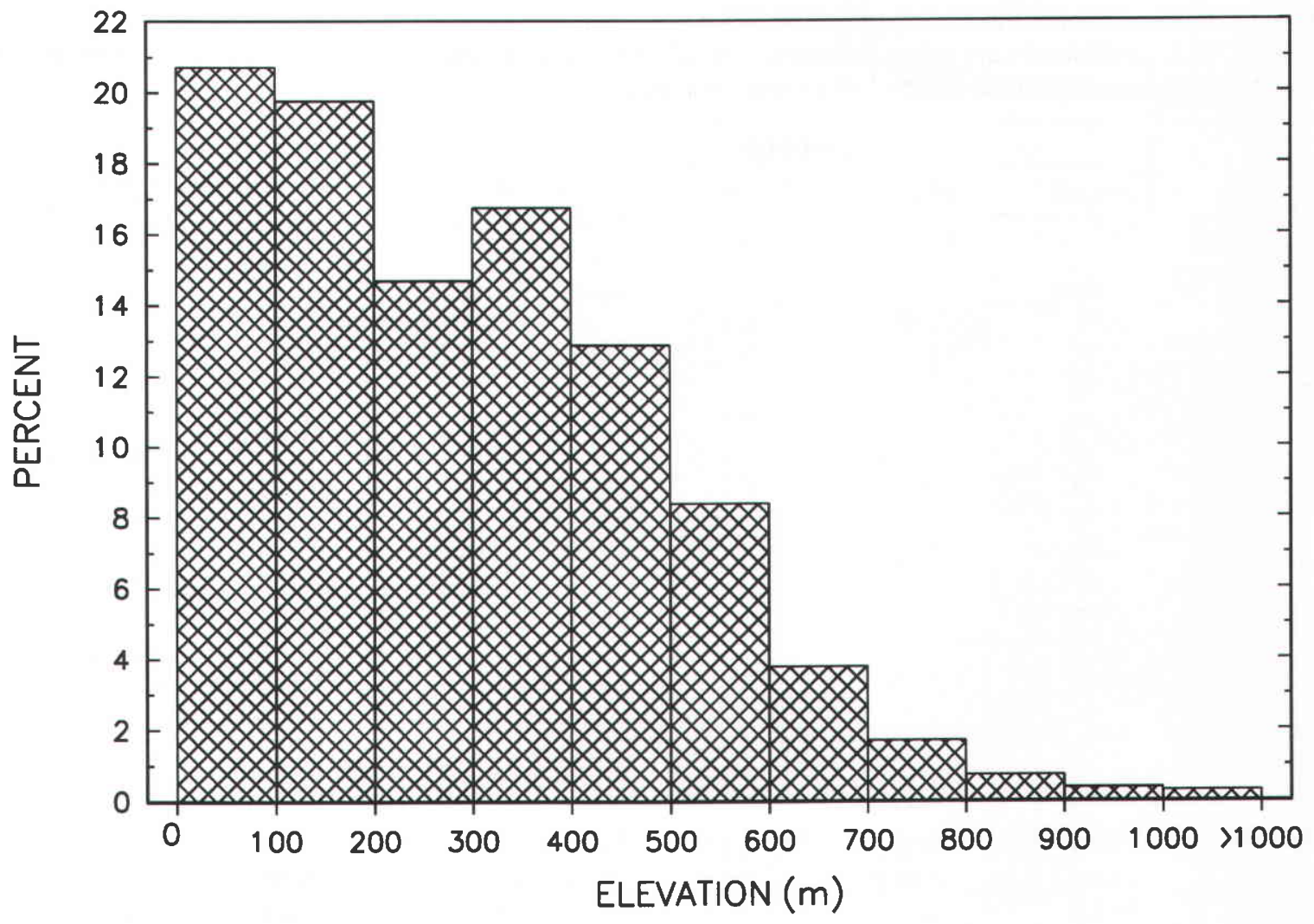

Figure 1. - Distribution of elevation in the northeastern U.S. (from $76^{\circ} \mathrm{W}$ longitude and $41^{\circ} \mathrm{N}$ latitude north and east through New England) as determined from a 30-arc-second digital elevation model.

from 2 to 619 meters in elevation. Although some mountainous areas in the northeast extend considerably higher, only 7 percent of the total land area of the region is above $600 \mathrm{~m}$. (Fig. 1). In addition, since the average environmental lapse rate generally is linear (Lydolph 1985), temperature trends derived from the data can be projected to higher elevations with reasonable confidence.

To analyze regional and elevational trends in maximum and minimum daily temperature, multiple linear regressions were performed for average monthly values against latitude, longitude, and elevation. Table 1 shows the results of these regressions. The adjusted $\mathrm{R}^{2}$ values indicate that the equations explain between 56 and 93 percent of the observed spatial variation (mean $=77$ percent) with estimated standard errors among months of from 0.51 to $1.59^{\circ} \mathrm{C}$. The $\mathrm{R}^{2}$ values generally are higher for winter months when local heating is less important relative to regional temperature gradients. In general, predicted temperatures are in good agreement with observed values across the region (Figs. 2, 3).

Across the region, the dominant trend is a decrease in temperature with increasing latitude, a gradient that is steeper during winter months than summer months (Table 1). This pattern is typical in middle latitude regions because during the winter, both the angle of the sun's rays and day length decrease with latitude, while during the summer, solar angle and day length decrease in opposite directions. For all months, the minimum daily temperature gradient is steeper than the maximum daily temperature gradient, indicating greater daily temperature fluctuations at higher latitudes.
The longitude coefficients show that, in general, temperatures increase from east to west within the region (Table 1). For maximum daily temperature, this trend is steeper during spring and summer months and is even slightly reversed during winter months, suggesting a role of the ocean in moderating temperatures. Longitude coefficients for minimum daily temperature also are smallest for winter months, although no seasonal pattern is evident throughout the remainder of the year.

Elevation coefficients show no obvious seasonal trends although minimum temperature coefficients consistently are more negative than maximum temperature coefficients (Table 1). This may reflect the occurrence of free convection during the day, which tends to dampen vertical temperature gradients. On average, the coefficients show a decrease of approximately $5.4^{\circ} \mathrm{C}$ per $1000 \mathrm{~m}$ increase in elevation for maximum daily temperatures and $7.6^{\circ} \mathrm{C}$ per $1000 \mathrm{~m}$ for minimum daily temperatures. The mean of all elevation coefficients combined gives an average temperature decrease of $6.5^{\circ} \mathrm{C}$ per $1000 \mathrm{~m}$, the rate generally accepted by climatologists as the average environmental lapse rate (Lydolph 1985).

Between April and September maximum daily temperatures were significantly lower at sites located along the seacoast than at sites only slightly further inland. Since this coastal influence counters the dominant trends for the remainder of the region, but affects only a small area, 15 stations located within approximately $20 \mathrm{~km}$ of the ocean were omitted from the analysis above for these months. Although the area represented by these stations is unlikely to play a major role in 
Table 1.-Regression coefficients and statistics for monthly mean maximum and minimum temperatures across the northeastern U.S. Coefficients are significant at $p<0.05$. Number of values $=164$ except for April through September maximum temperatures where 15 coastal sites were omitted.

\begin{tabular}{|c|c|c|c|c|c|c|c|}
\hline \multirow[b]{2}{*}{ Month } & \multicolumn{4}{|c|}{ Coefficients } & \multirow[b]{2}{*}{ Mean } & \multirow[b]{2}{*}{ Adj. $\mathrm{R}^{2}$} & \multirow[b]{2}{*}{ Root MSE } \\
\hline & Constant & Latitude & Longitude & Elevation & & & \\
\hline & ${ }^{\circ} \mathrm{C}$ & ${ }^{\circ} \mathrm{C} / \mathrm{deg}$ & ${ }^{\circ} \mathrm{C} / \mathrm{deg}$ & ${ }^{\circ} \mathrm{C} / \mathrm{m}$ & ${ }^{\circ} \mathrm{C}$ & & ${ }^{\circ} \mathrm{C}$ \\
\hline \multicolumn{8}{|c|}{ Maximum daily temperature: } \\
\hline Jan max & 67.98 & -1.466 & -0.062 & -0.00562 & -0.58 & 0.90 & 0.72 \\
\hline Feb max & 67.27 & -1.385 & -0.084 & -0.00535 & 0.57 & 0.91 & 0.67 \\
\hline Mar max & 54.14 & -1.113 & -0.002 & -0.00522 & 5.49 & 0.88 & 0.66 \\
\hline Apr max & 54.60 & -1.110 & 0.097 & -0.00556 & 12.65 & 0.83 & 0.77 \\
\hline May max & 42.15 & -0.634 & 0.079 & -0.00451 & 19.46 & 0.61 & 0.88 \\
\hline Jun max & 36.40 & -0.467 & 0.128 & -0.00519 & 24.42 & 0.65 & 0.76 \\
\hline Jul max & 42.57 & -0.497 & 0.099 & -0.00623 & 26.98 & 0.73 & 0.69 \\
\hline Aug $\max$ & 44.93 & -0.586 & 0.104 & -0.00639 & 25.85 & 0.80 & 0.62 \\
\hline Sep max & 41.17 & -0.702 & 0.164 & -0.00601 & 21.55 & 0.85 & 0.57 \\
\hline Oct max & 43.73 & -0.845 & 0.133 & -0.00544 & 15.78 & 0.88 & 0.58 \\
\hline Nov max & 56.71 & -1.159 & 0.039 & -0.00631 & 8.55 & 0.93 & 0.51 \\
\hline Dec max & 63.58 & -1.430 & 0.009 & -0.00616 & 1.60 & 0.92 & 0.68 \\
\hline \multicolumn{8}{|c|}{ Minimum daily temperature: } \\
\hline Jan min & 65.33 & -1.942 & 0.118 & -0.00805 & -10.97 & 0.78 & 1.59 \\
\hline Feb min & 65.96 & -1.914 & 0.102 & -0.00866 & -10.43 & 0.80 & 1.52 \\
\hline Mar min & 49.59 & -1.375 & 0.083 & -0.00831 & -4.92 & 0.83 & 1.06 \\
\hline Apr min & 29.84 & -0.915 & 0.160 & -0.00696 & 1.00 & 0.77 & 0.96 \\
\hline May min & 26.69 & -0.735 & 0.172 & -0.00651 & 6.50 & 0.65 & 1.07 \\
\hline Jun min & 26.80 & -0.654 & 0.196 & -0.00682 & 11.78 & 0.65 & 1.08 \\
\hline Jul min & 38.61 & -0.757 & 0.136 & -0.00798 & 14.56 & 0.65 & 1.21 \\
\hline Aug min & 42.11 & -0.871 & 0.143 & -0.00792 & 13.68 & 0.67 & 1.25 \\
\hline Sep min & 37.07 & -0.937 & 0.193 & -0.00743 & 9.57 & 0.66 & 1.32 \\
\hline Oct min & 27.67 & -0.812 & 0.171 & -0.00711 & 3.97 & 0.56 & 1.45 \\
\hline Nov min & 29.32 & -0.939 & 0.158 & -0.00706 & -0.79 & 0.70 & 1.16 \\
\hline Dec min & 48.11 & -1.627 & 0.212 & -0.00791 & -7.79 & 0.80 & 1.37 \\
\hline
\end{tabular}

regional modeling exercises, coastal correction factors derived from the omitted stations could be applied. We estimated correction factors by comparing residual values (from equations in Table 1 and observed coastal site values) with distance from the ocean. During April, May, June, July, August, and September, maximum daily temperatures decreased linearly by $3.0,4.0,3.5,3.0,2.5$, and $1.7^{\circ} \mathrm{C}$, respectively, between approximately $20 \mathrm{~km}$ inland and the seacoast. This effect was not seen for any other month.

Figures 4 and 5 show digital maps of average maximum and minimum daily temperature for January and July, generated by combining the equations in Table 1 with the digital elevation model of the region. Particularly evident is the steeper latitude temperature gradient in winter than in summer months.

\section{Humidity}

Atmospheric humidity is measured only at first-order weather stations. Because there are relatively few of these stations, we have not tried to conduct regional analyses using measured humidity data. In humid climates such as the northeastern United States, the dewpoint temperature is approximately equal to the daily minimum temperature, because nighttime air temperatures typically decrease only to the point at which dew formation begins (Gentilli 1955). Thus, we estimate humidity, expressed as water vapor pressure, from predicted daily minimum temperature using the relationship between temperature and saturation vapor pressure as given by Murray (1967).

Monthly average dewpoint temperatures for 1946-1965 were given for 27 stations in our area in the "Climatic Atlas of the United States" (EDS 1968). We used these data to test the assumption that average monthly minimum temperature, as calculated from Table 1 , is equal to average monthly dew point temperature (Fig. 6). For most stations and months, minimum temperatures predicted from the latitude-longitude-elevation regressions were within $2^{\circ} \mathrm{C}$ of the measured average dewpoints. The possible error in predicted vapor pressure is approximately $0.1 \mathrm{kPa}$ at $0^{\circ} \mathrm{C}$, increasing to $0.2 \mathrm{kPa}$ at $20^{\circ} \mathrm{C}$. Slight seasonal biases may occur, but there is no overall bias in the predictions for most locations. For Mt. Washington, New Hampshire, at an elevation of $1909 \mathrm{~m}$, the predicted monthly minimum temperature is approximately $5^{\circ} \mathrm{C}$ lower than the average monthly dewpoint. This bias probably results from the high level of cloud cover experienced at the summit of Mt. Washington, and may not be general at lower high elevation sites. 

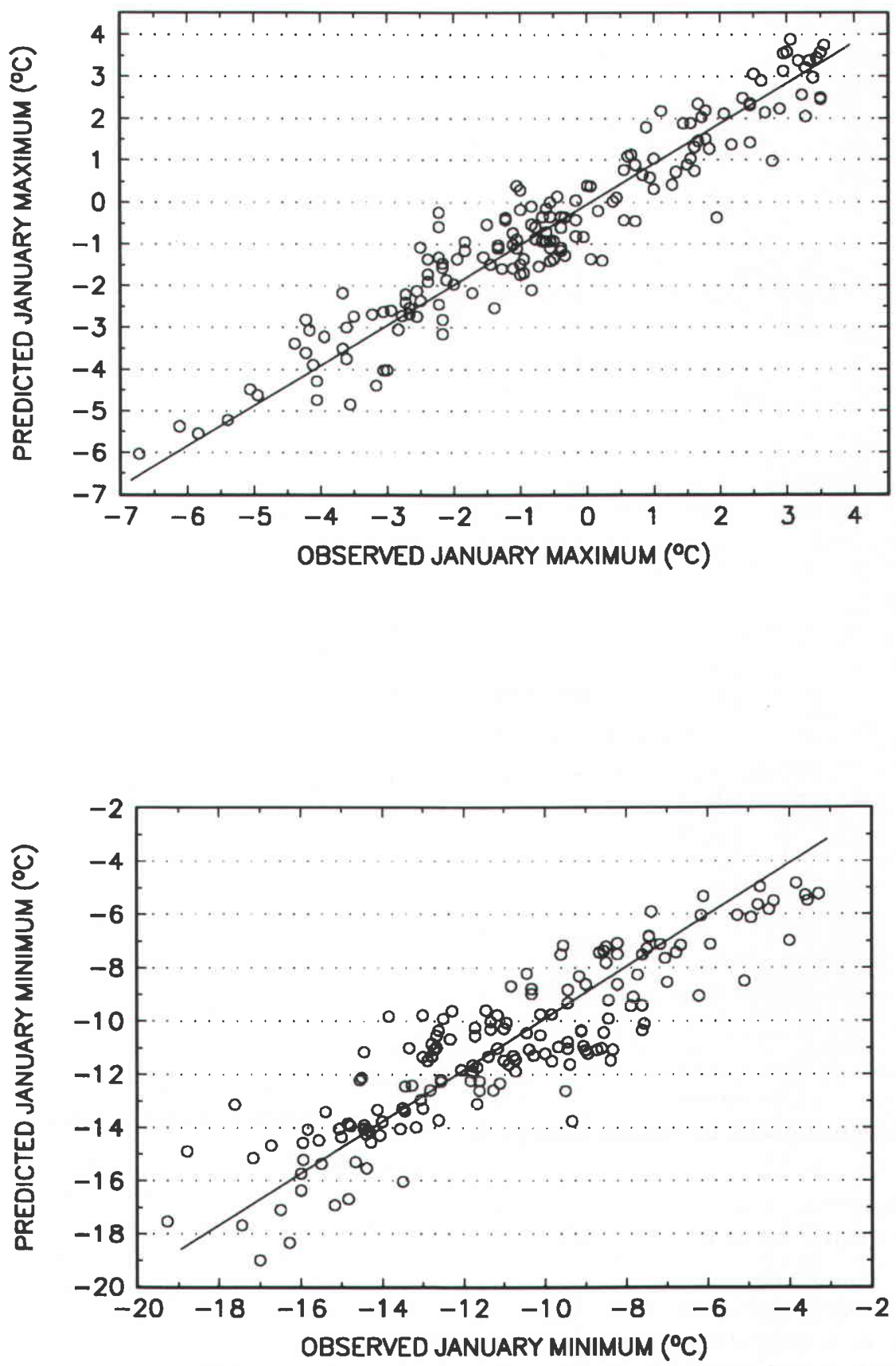

Figure 2.-Predicted versus observed maximum and minimum daily temperatures for January (diagonal lines indicate 1:1 relationship). 

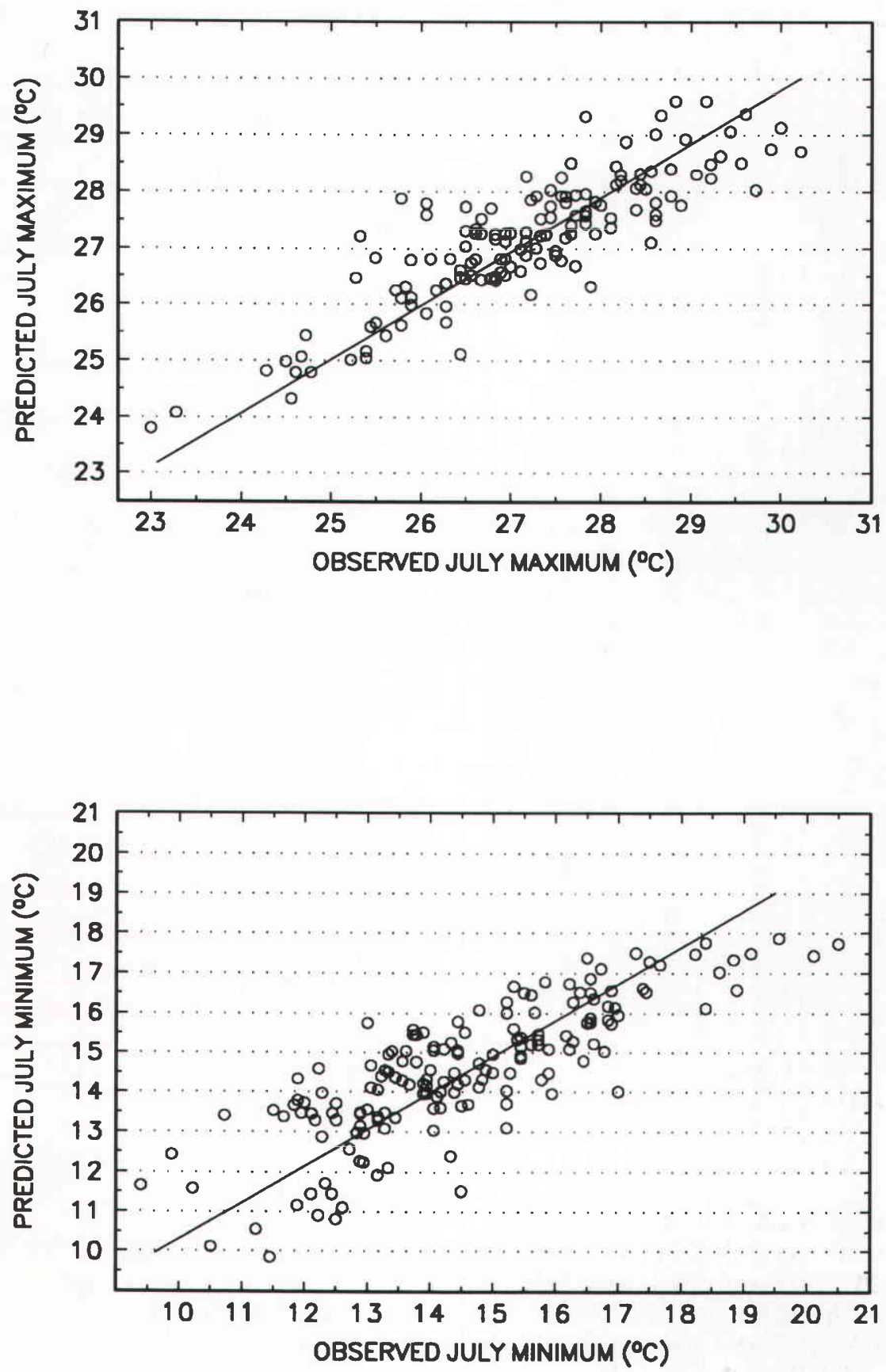

Figure 3. - Predicted versus observed maximum and minimum daily temperatures for July (diagonal lines indicate 1:1 relationship). 


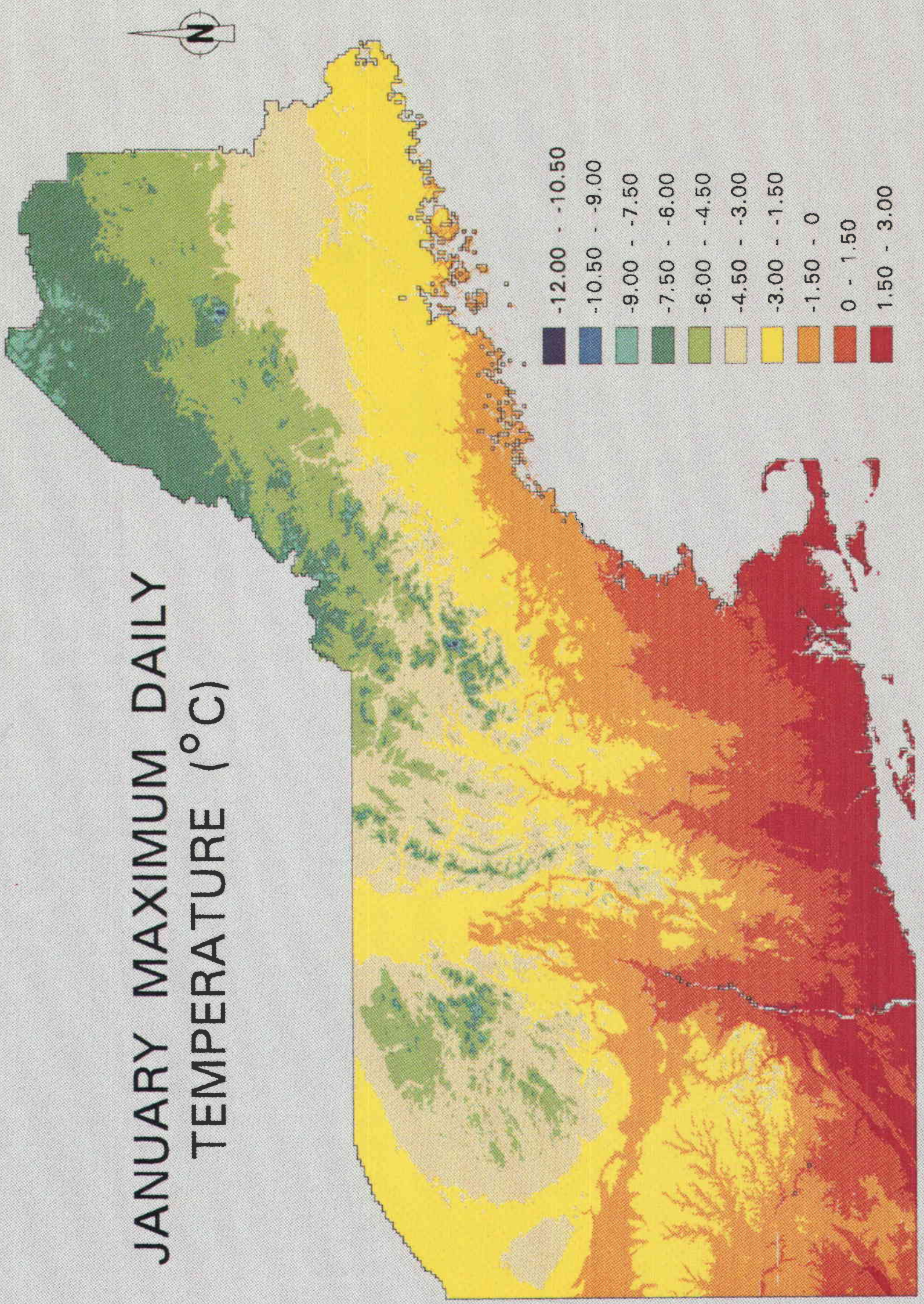




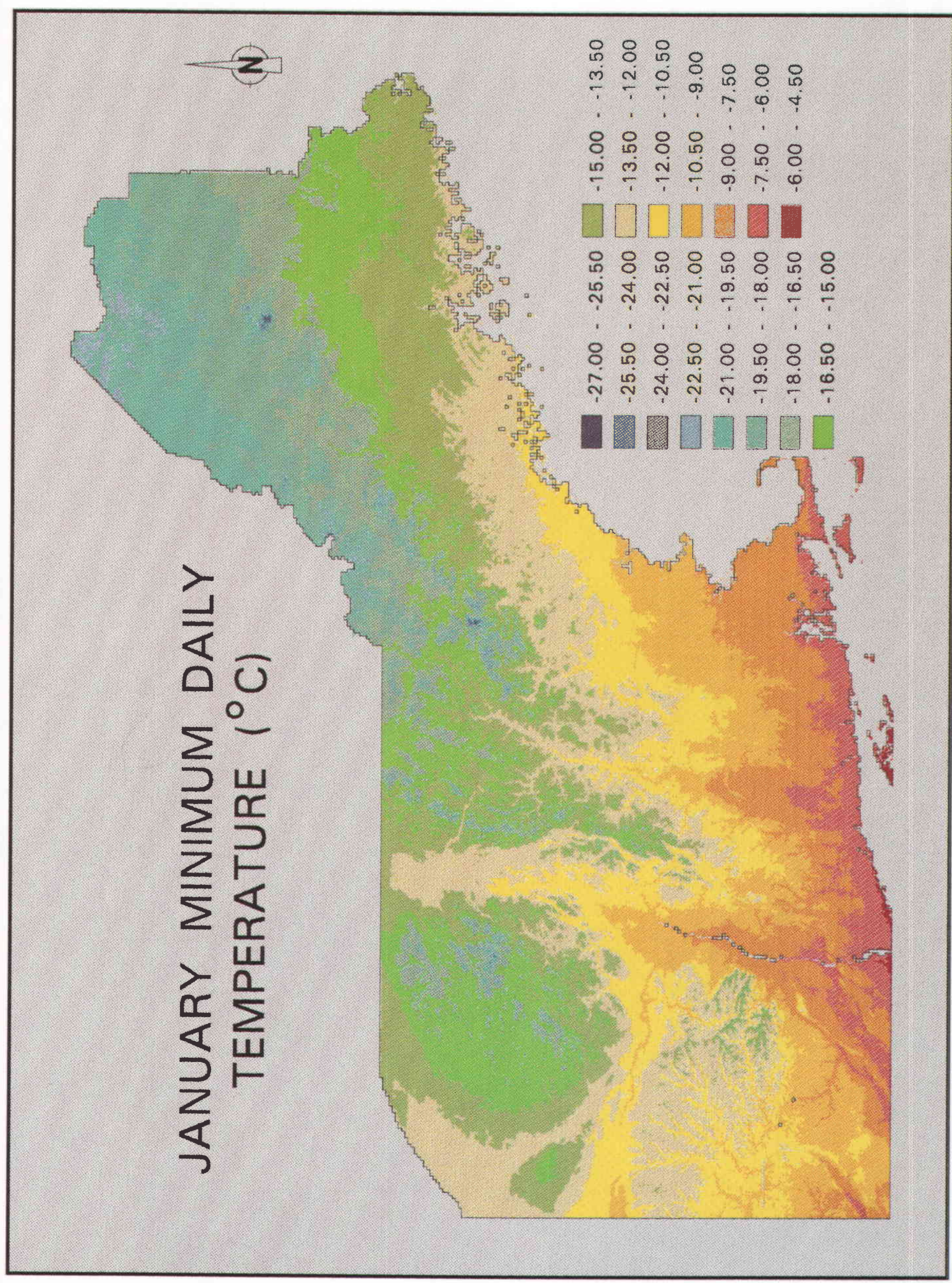

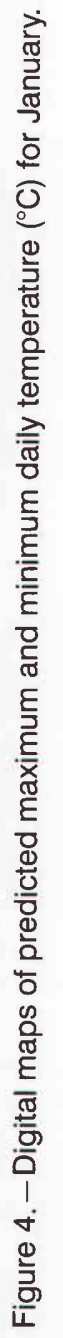




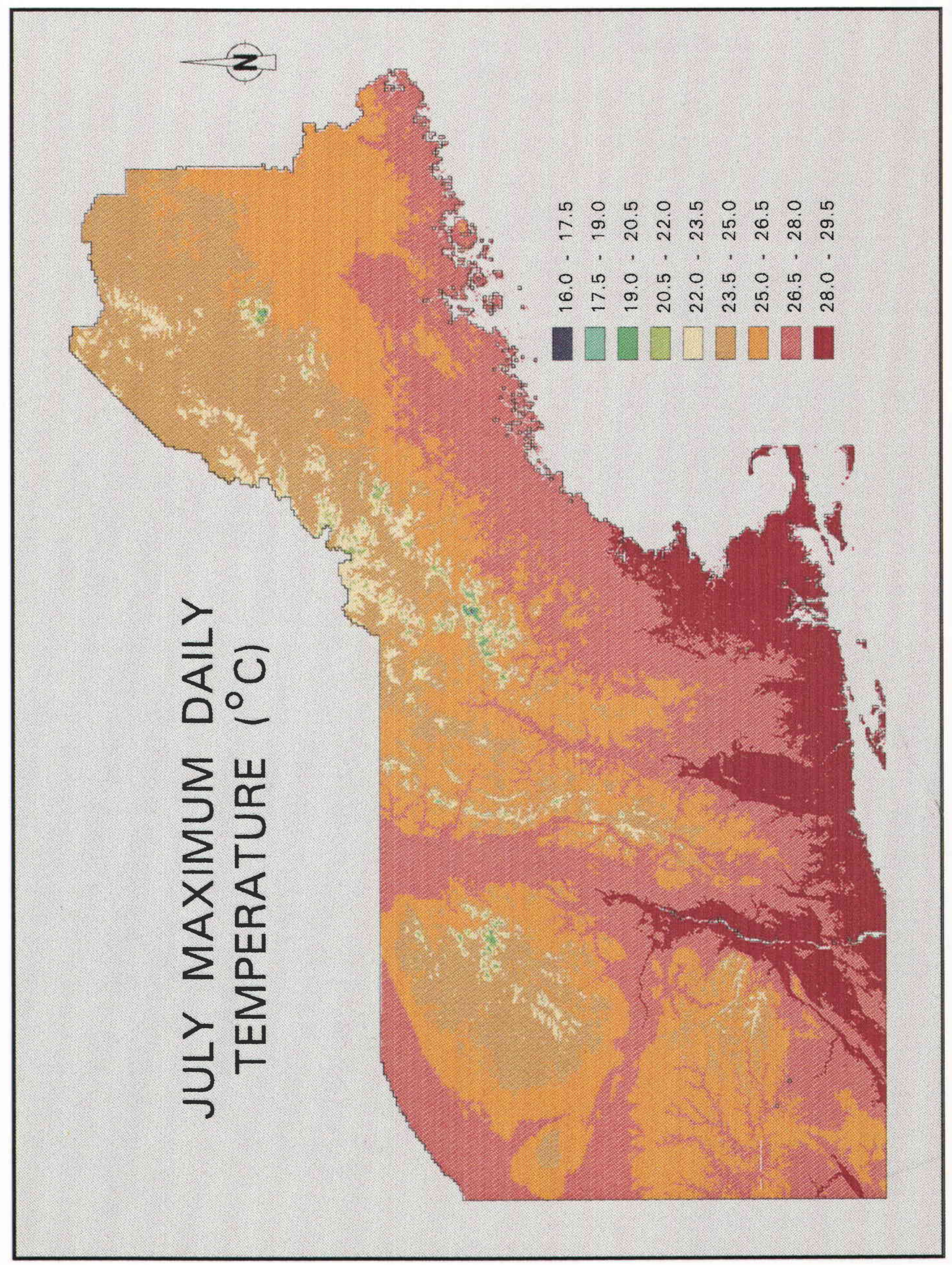




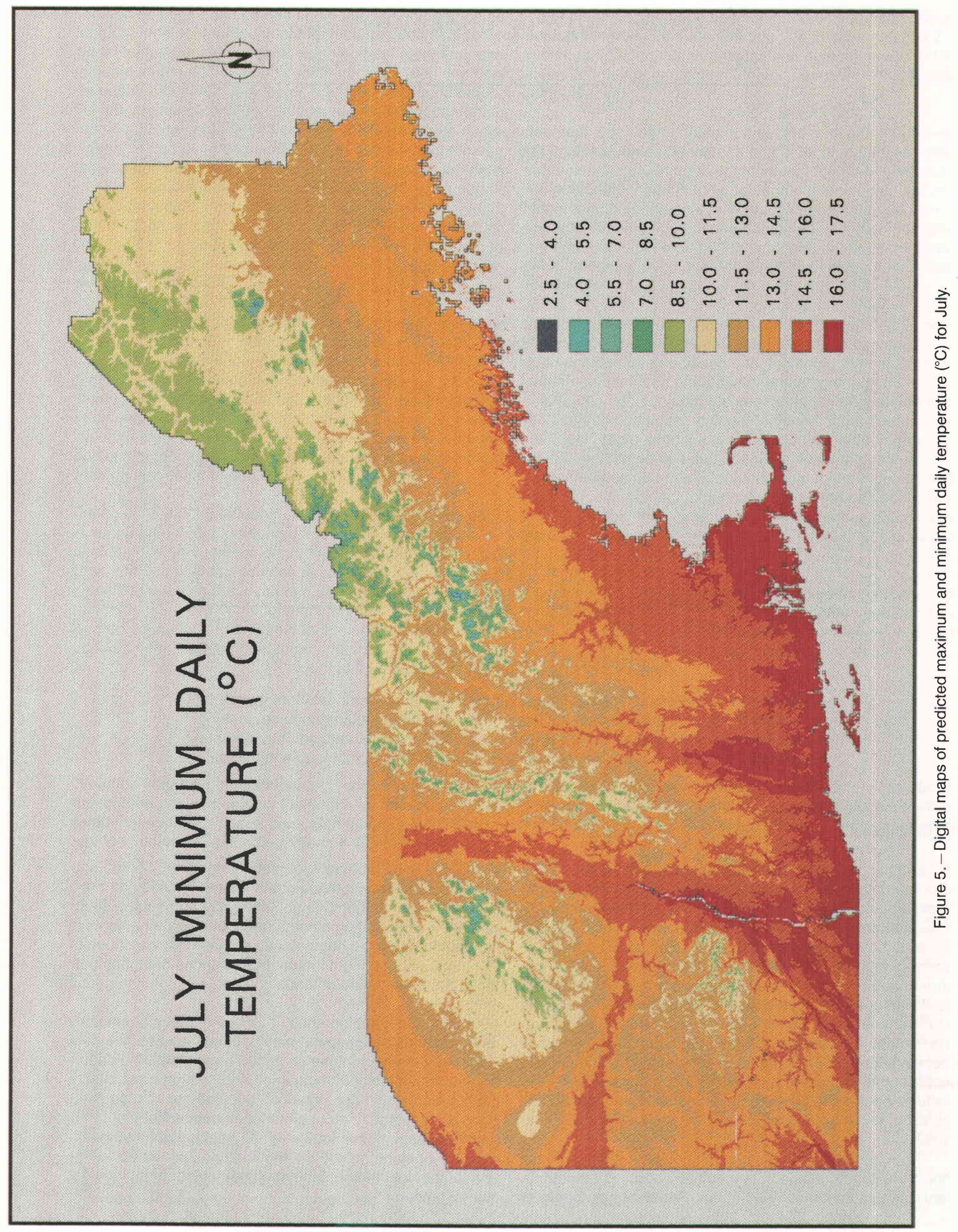




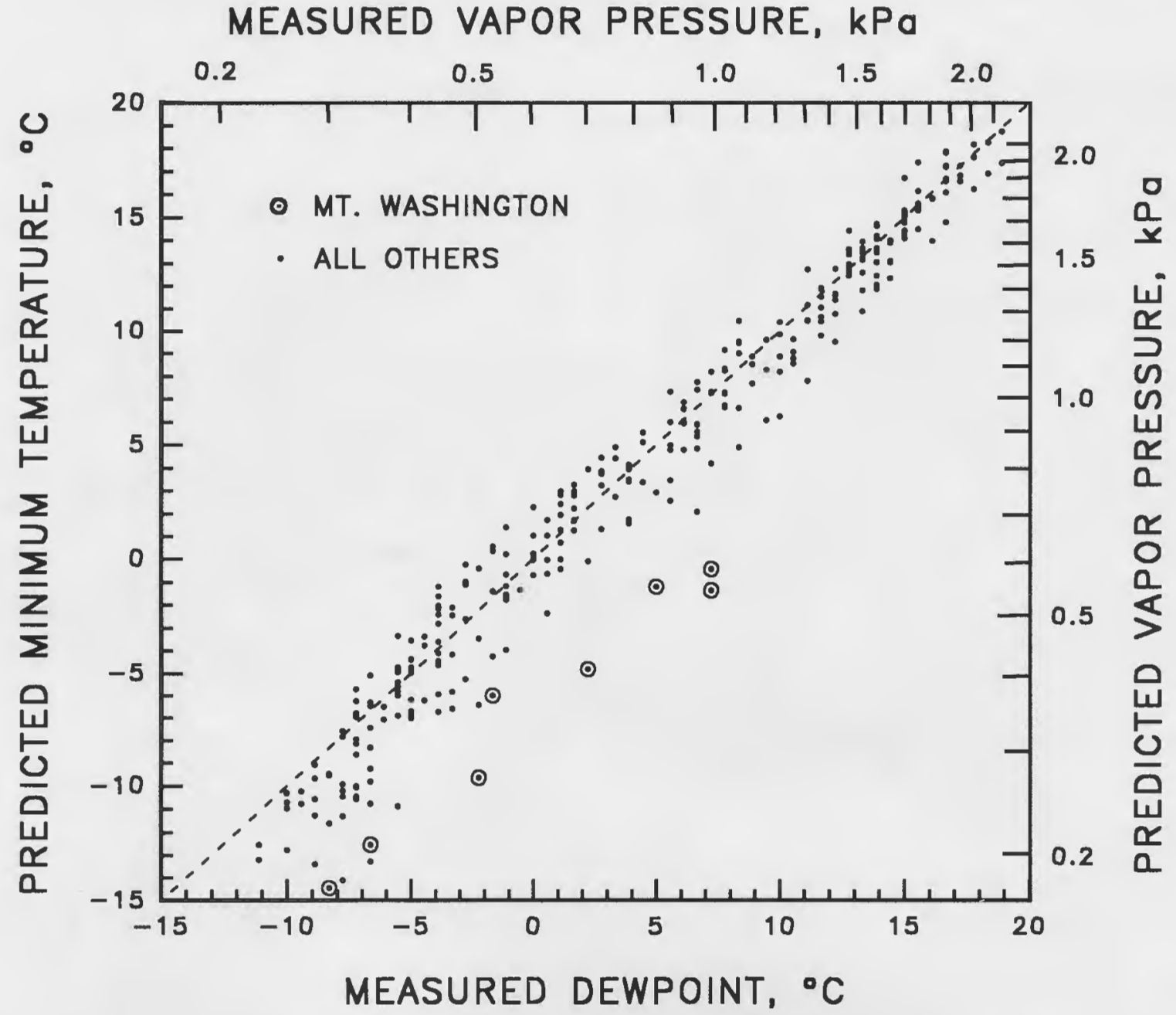

Figure 6.-Minimum monthly temperature and corresponding vapor pressure, predicted from Table 1, versus measured average monthly dewpoint temperature and corresponding vapor pressure, for 27 stations in New England, New York, New Jersey, and Pennsylvania. Four additional Mt. Washington points and three other points are off the scale to the lower left.

\section{Precipitation}

A regional precipitation analysis was conducted using monthly data from 310 weather stations across New York and New England. The stations ranged from 2 to $1909 \mathrm{~m}$ in elevation, although most were located below $600 \mathrm{~m}$. The data consisted of average monthly precipitation amounts from 30 years of records (1951-1980) reported by NOAA (1982), with the exceptions of NOAA stations at Slide Mountain, New York (1945-1990) and Mt. Mansfield, Vermont (1955-1990), and the Hubbard Brook Experimental Forest, New Hampshire, (1969-1986, Federer et al. 1990). We do not distinguish between precipitation forms in this report because the applications for which this analysis is intended generally include partitioning between rain and snow, as well as calculating snow accumulation and melt (Aber and Federer 1992).

Important spatial trends in precipitation occur at several different scales across the study area. Regionally, precipitation

decreases with increasing distance from the ocean, and locally, precipitation increases with elevation (Dingman 1981, Dingman et al. 1988, Ollinger et al. 1993). Elevational increases in precipitation amount occur primarily as a result of orographic uplifting of air masses, although the magnitude of this increase depends on many factors and is difficult to predict (Lovett and Kinsman 1990).

Estimating the elevation effect on monthly precipitation from region-wide multiple regressions is difficult because, for many areas within the region, the elevation range of available data is limited. In addition, within some areas represented by the precipitation data base, elevation is correlated strongly with geographic position, making the two factors difficult to separate statistically. These problems are most prevalent in southern New England, where the few stations that extend above several hundred meters in elevation lie inland, away from flat coastal areas. 
To evaluate the effects of elevation, we used data only from the area above $43^{\circ} \mathrm{N}$ latitude and between $71^{\circ}$ and $76^{\circ} \mathrm{W}$ longitude (New Hampshire, Vermont, and northern New York). This area contains most of the region's elevational variation, with no correlation between elevation and geographic location. Monthly preccipitation data were available for 91 stations within this area. Elevation effects from this sub-region were determined by multiple regression analyses of monthly precipitation on elevation, latitude, and longitude (where significant at $p$ $<.10)$. These elevation effects were subtracted from station data for the whole region in order to normalize all values to $0 \mathrm{~m}$ elevation, an approach previously used by Dingman et al. (1988). The "sea-level" precipitation values were then used to evaluate regional trends for each month by regression on latitude and longitude.

Monthly precipitation patterns resulting from this analysis are shown in Table 2. The latitude and longitude coefficients are consistently negative, corresponding to the regional trend of decreasing precipitation with increasing distance from the ocean. The coefficients also indicate that the trend fluctuates seasonally. During the winter months, precipitation decreases by more than 50 percent from the southeast to northwest portions of the region. During the summer months, the trend is much less distinct.

During June and July, there is a slight decrease in precipitation at sites located along the seacoast. The relatively cool temperature of the ocean limits the occurrence of local convection, which contributes a significant portion of the precipitation during these months. To allow better representation of the dominant trends for the remainder of the region, we omitted 23 stations lying within $20 \mathrm{~km}$ of the coast from the precipitation analysis for June and July. The observed decrease (from predicted values) in monthly precipitation at coastal stations was approximately $1.75 \mathrm{~cm}$ in June and 2.0 $\mathrm{cm}$ in July, becoming undetectable at approximately $20 \mathrm{~km}$ inland (the same range in which maximum daily temperatures were affected).

Elevation coefficients (obtained from the sub-region above $43^{\circ} \mathrm{N}$ latitude and between $71^{\circ} \mathrm{W}$ and $76^{\circ} \mathrm{W}$ longitude) differ significantly from winter to summer, although the differences are less pronounced than for latitude and longitude. The elevation effects on monthly precipitation range from just over 5 $\mathrm{cm} / 1000 \mathrm{~m}$ in June to $7.7 \mathrm{~cm} / 1000 \mathrm{~m}$ in December. Annually, this amounts to a $74 \mathrm{~cm} / 1000 \mathrm{~m}$ increase, which is the same value obtained by Dingman (1981) for Vermont and New Hampshire.

Predicted values from the equations in Table 2 agree with observed values with mean absolute residual varying from 0.66 to $1.25 \mathrm{~cm}$ among months. Residuals are greatest for winter months when precipitation is the most variable across the region. Figure 7 shows annual patterns of observed and predicted precipitation at three locations within the region. Although precipitation across much of the region is evenly distributed throughout the year, most coastal areas experience greater amounts in the winter than in the summer, and northern inland areas experience the reverse trend. Values predicted from the equations in Table 2 also exhibit these trends, indicating that the regression equations adequately capture this shifting seasonal pattern.

Figure 8 shows digital precipitation coverages for January and July, generated by combining the appropriate equations in Table 2 with the DEM. Precipitation has a steeper regional gradient in January than in July, just as temperature does.

Table 2. - Regression coefficients and statistics for monthly precipitation. Elevation coefficients were determined from the sub-region above $43^{\circ} \mathrm{N}$ latitude and between $71^{\circ}$ and $76^{\circ} \mathrm{W}$ longitude. Other coefficients were determined after removing elevation effects from station data. Coefficients are significant at $p<.05$. Number of values $=310$ except June and July where 23 coastal sites were omitted.

\begin{tabular}{|c|c|c|c|c|c|c|c|}
\hline \multirow[b]{2}{*}{ Month } & \multicolumn{4}{|c|}{ Coefficients } & \multirow[b]{2}{*}{ Mean } & \multirow[b]{2}{*}{ Adj. $\mathrm{R}^{2}$} & \multirow[b]{2}{*}{ Resid.气 } \\
\hline & Constant & Latitude & Longitude & Elevation & & & \\
\hline & $\mathrm{cm}$ & $\mathrm{cm} / \mathrm{deg}$ & $\mathrm{cm} / \mathrm{deg}$ & $\mathrm{cm} / \mathrm{m}$ & $\mathrm{cm}$ & & $\mathrm{cm}$ \\
\hline Jan & 104.11 & -1.119 & -.674 & .0067 & 8.10 & 0.48 & 1.15 \\
\hline Feb & 94.98 & -1.018 & -.615 & .0069 & 7.32 & 0.47 & 1.09 \\
\hline Mar & 119.02 & -1.505 & -.642 & .0072 & 8.85 & 0.63 & 1.05 \\
\hline Apr & 79.43 & -1.001 & -.390 & .0056 & 9.01 & 0.52 & .86 \\
\hline May & 54.49 & -.609 & -.280 & .0052 & 8.92 & 0.51 & .66 \\
\hline Jun & 21.48 & -.197 & -.071 & .0055 & 8.94 & 0.61 & .67 \\
\hline Jul & 26.83 & -.143 & -168 & .0051 & 8.99 & 0.48 & .78 \\
\hline Aug & 53.45 & -.614 & -.252 & .0058 & 9.79 & 0.41 & .91 \\
\hline Sep & 51.10 & -.599 & -.232 & .0055 & 9.47 & 0.37 & .87 \\
\hline Oct & 59.44 & -.545 & -.385 & .0055 & 8.94 & 0.42 & .82 \\
\hline Nov & 91.98 & -.894 & -.617 & .0077 & 9.98 & 0.41 & .96 \\
\hline Dec & 106.50 & -1.059 & -.724 & .0077 & 9.61 & 0.47 & 1.25 \\
\hline
\end{tabular}

aResid. shows mean residual values from predicted vs. observed regressions. 


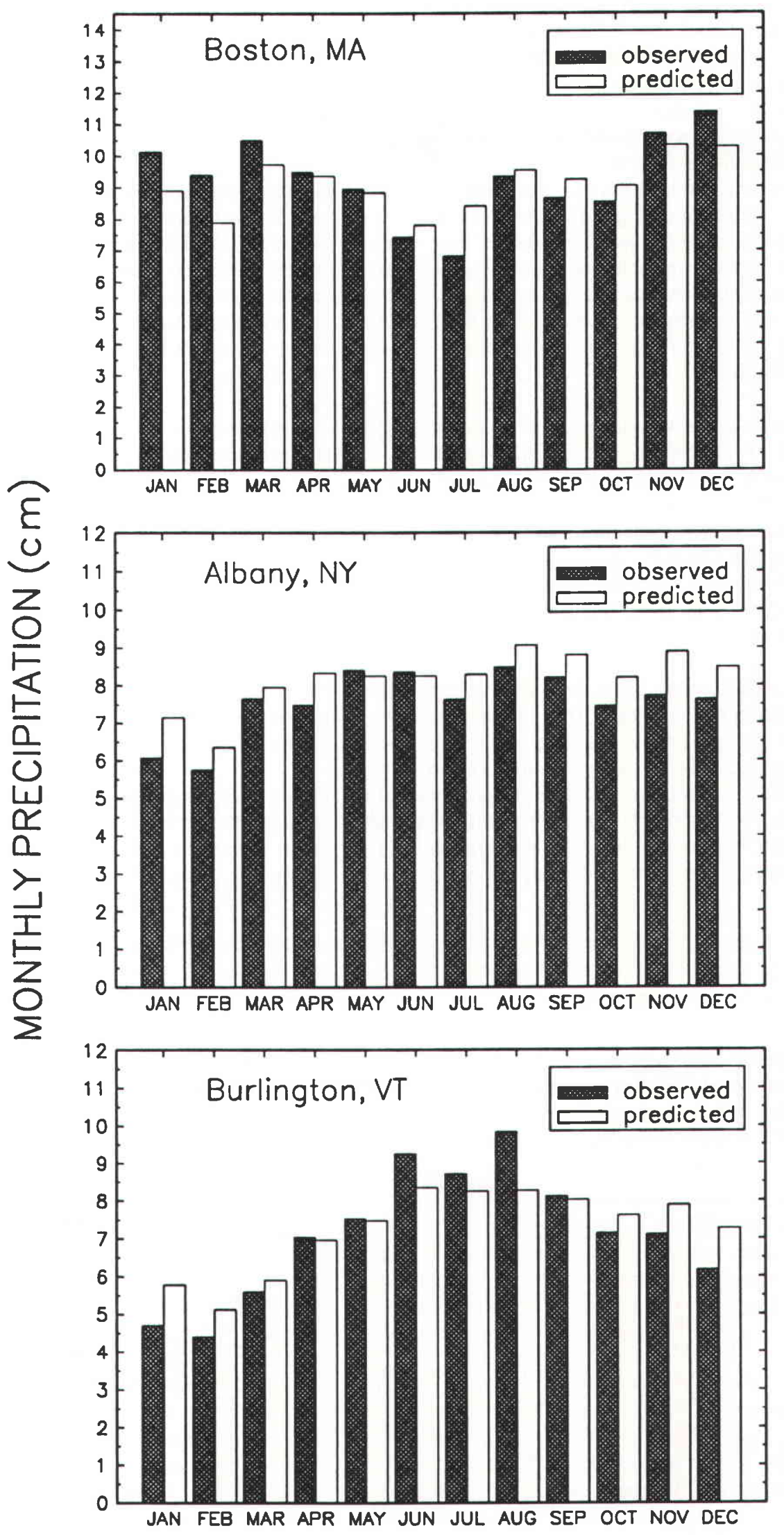

Figure 7. - Predicted and observed precipitation at three locations within the study area. Note the shifting annual pattern from coastal (Boston) to inland (Burlington) locations. 


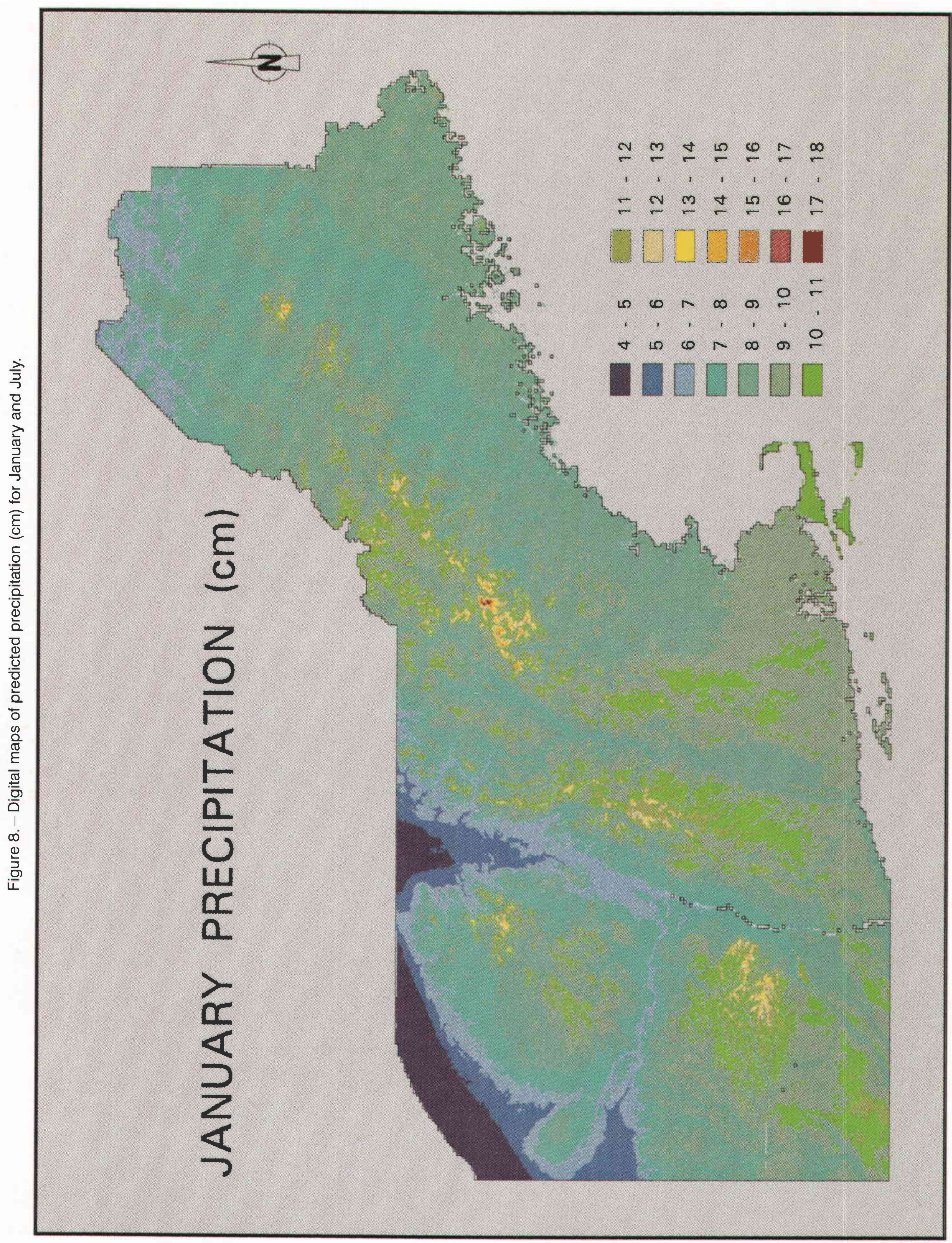




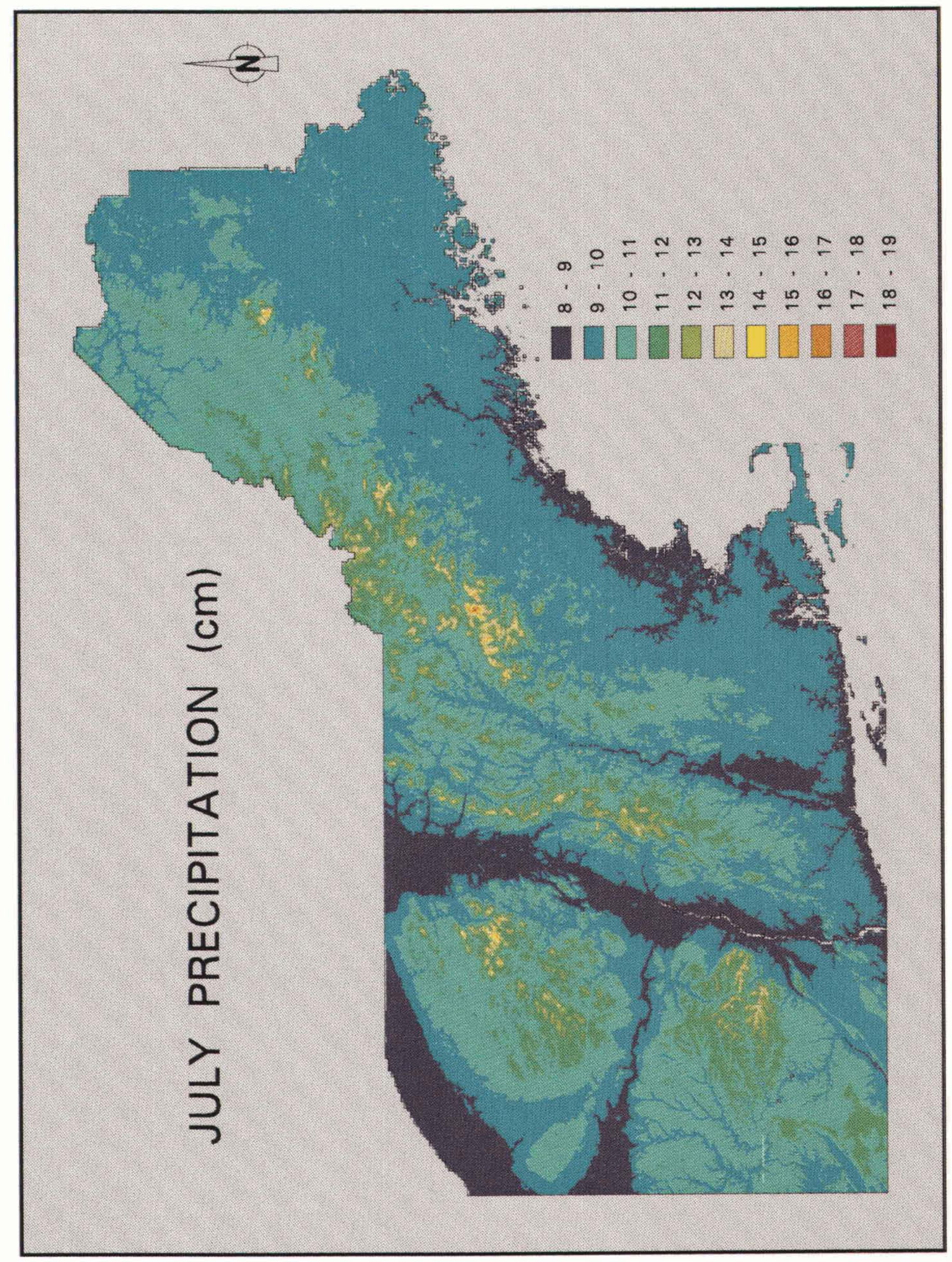




\section{Solar Radiation}

Extensive, region-wide solar radiation data have never been routinely collected. Therefore, it is not possible to conduct a regional analysis using station data alone as was done for temperature and precipitation. Instead, we use the concept of potential radiation, defined as the amount of radiation that would be received by a surface in the absence of the earth's atmosphere. Daily potential radiation can be calculated for any location as a function of day of the year, latitude, slope and aspect, using well-known trigonometric algorithms as given by Swift (1976). Actual radiation estimates are obtained by multiplying calculated potential radiation by the ratio of measured to potential radiation, as determined from data for several locations within the region. This ratio is reasonably constant when using average monthly values.

Measured radiation data were obtained from two sources. The U.S. Department of Commerce has published 5 to 17 years of data for solar radiation on a horizontal surface at 10 locations within the northeastern region (EDS 1955-1972). Additional data come from the Hubbard Brook Experimental Forest for the years 1960 to 1988 (Federer et al. 1990). Table 3 lists the locations of all sites used along with the periods of data collection.

For each site listed in Table 3, average monthly measured radiation and average monthly potential radiation were determined, and their ratios calculated. Annual patterns of the ratios were very similar across all sites studied, indicating that the annual pattern of atmospheric absorption does not change substantially across the region. Thus, we averaged ratios from all 11 sites to provide monthly ratios of actual to potential radiation for the region (Fig. 9). The ratio is close to 0.5 for all months except November and December, which consistently are lower because of greater cloudiness.

To generate monthly radiation coverages for the northeast region, potential radiation estimates were generated using the
Table 3. - Solar radiation measurement sites.

\begin{tabular}{lccc}
\hline Site & Latitude & Longitude & $\begin{array}{c}\text { Period of } \\
\text { data collection }\end{array}$ \\
\hline Blue Hill, MA & 42.3 & 71.1 & $1955-72$ \\
Boston, MA & 42.4 & 71.1 & $1955-68$ \\
Burlington, VT & 44.4 & 73.2 & $1963-72$ \\
Caribou, ME & 46.8 & 68.0 & $1955-72$ \\
Hubbard Brook, NH & 43.6 & 71.5 & $1960-88$ \\
thaca, NY & 42.5 & 76.7 & $1955-72$ \\
New York, NY & 40.7 & 74.0 & $1955-72$ \\
Newport, RI & 41.5 & 71.3 & $1955-72$ \\
Portland, ME & 43.7 & 70.3 & $1955-72$ \\
Sayville, NY & 40.6 & 73.1 & $1955-63$ \\
State College, PA & 40.8 & 77.9 & $1955-71$ \\
\hline
\end{tabular}

algorithms given by Swift (1976) with latitude, slope, and aspect data obtained from the DEM. These estimates were then multiplied by the ratio of measured to potential radiation for each corresponding month (Fig. 9), resulting in coverages of predicted solar radiation (Fig. 10). This approach allows predictions to be generated with higher spatial resolution than would be possible using a regional survey approach because it includes the effects of slope and aspect. Some bias may exist for mountaintop sites because increases in cloud cover received by these areas are expected to decrease incident radiation (Dingman 1981).

The radiation maps shown in Figure 10 reveal a large difference between the amount of spatial variation in summer and winter. In the winter, the low solar elevation creates steep gradients between north- and south-facing slopes, and between low and high latitudes. These factors are minimized in the summer when the sun's angle is much higher.

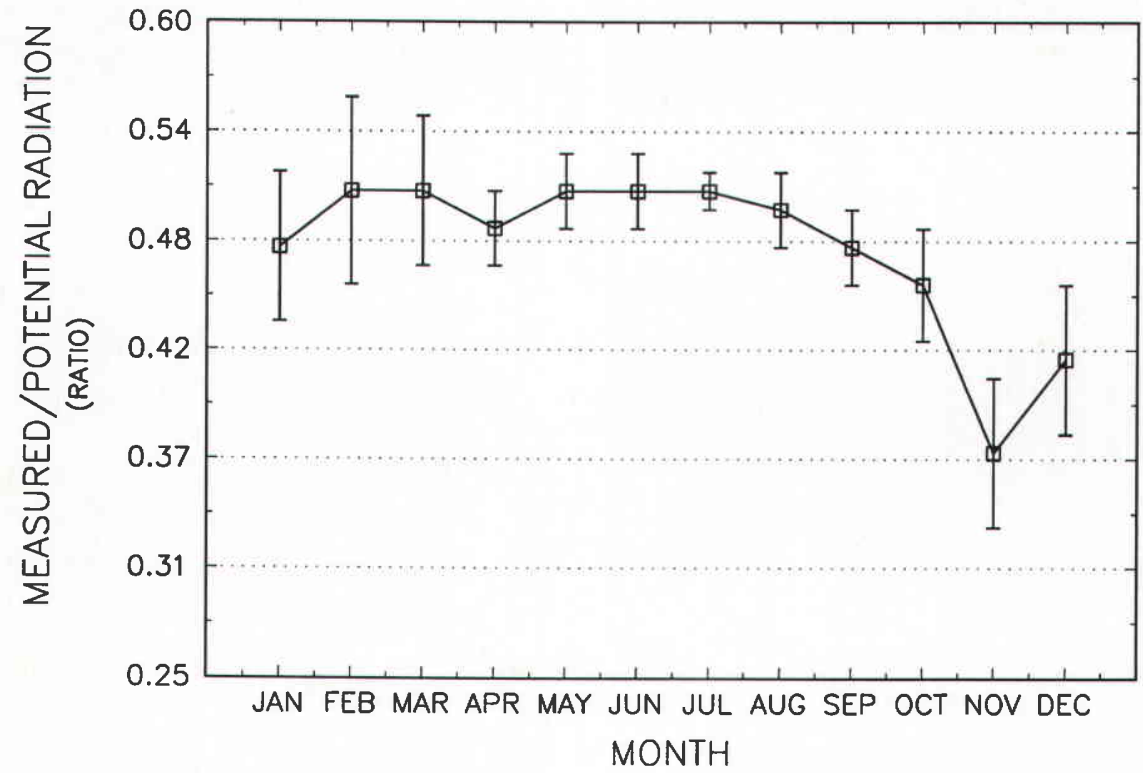

Figure 9. - Ratio of mean monthly measured radiation to potential radiation averaged over 11 stations. Error bars show plus and minus one standard deviation. 


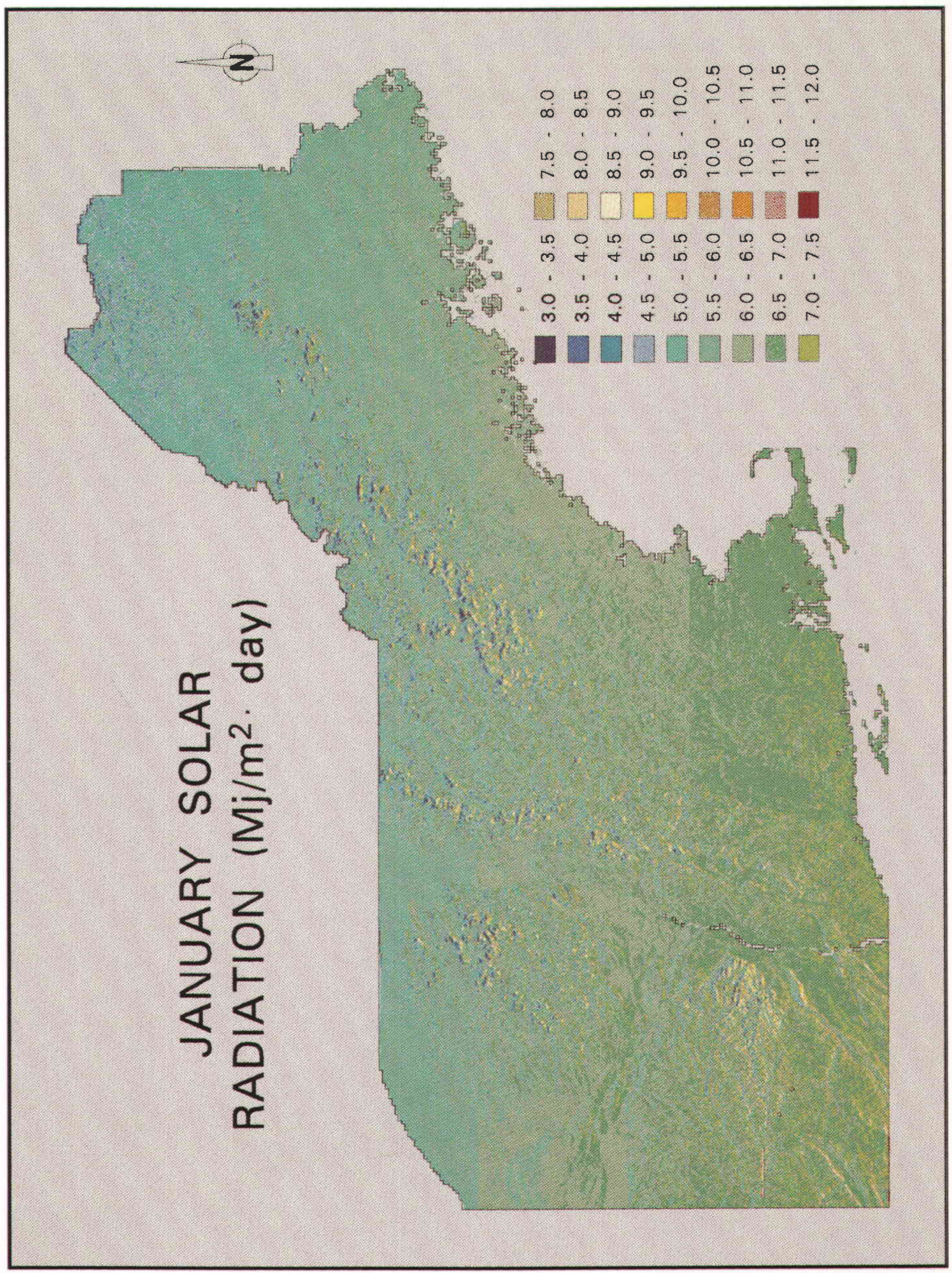




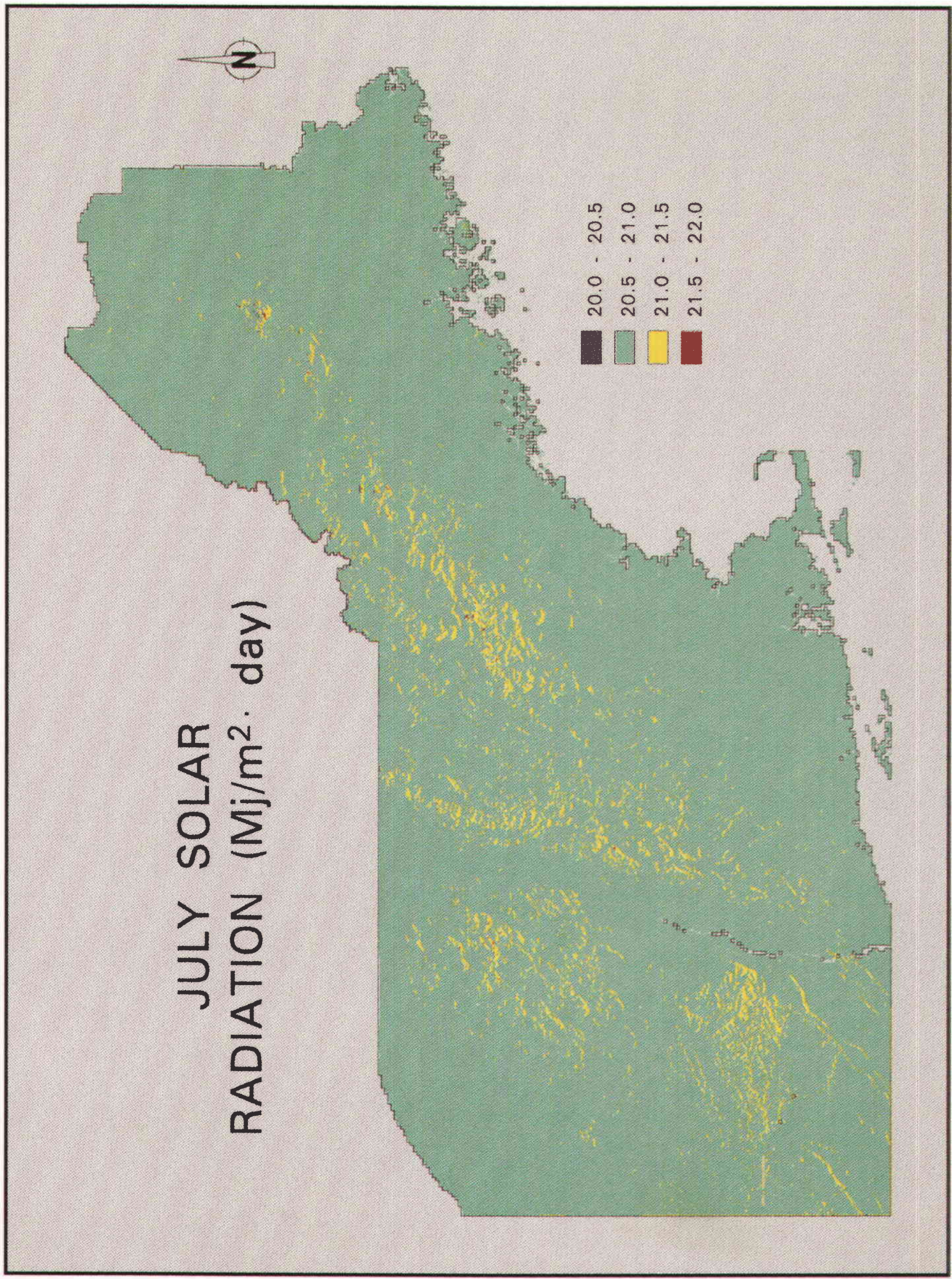

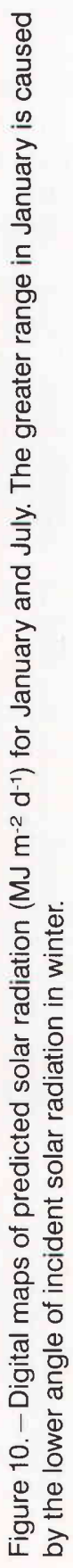




\section{Atmospheric Deposition}

\section{Wet Deposition}

Data representing volume-weighted mean annual concentrations of nine major ions $\left(\mathrm{NO}_{3}{ }^{-}, \mathrm{NH}_{4}{ }^{+}, \mathrm{SO}_{4}{ }^{2-}, \mathrm{H}^{+}\right.$, $\mathrm{Ca}^{2+}, \mathrm{Mg}^{2+}, \mathrm{K}^{+}, \mathrm{Na}^{+}$and $\mathrm{Cl}^{-}$) in precipitation for 26 sites across the region (including several sites in Pennsylvania) were obtained from the National Atmospheric Deposition Program/National Trends Network (NADP/NTN, 1991). The sites were evenly distributed across the region and contained between 4 and 11 years of data. Completeness criteria established by NADP/NTN were used to determine which data were suitable for use in computing long-term mean concentrations (NADP/NTN 1990). Annual means were then used to compute long-term, volume-weighted mean concentrations for each location.

Regional trends in ion concentration were evaluated by linear regression analyses of concentrations against latitude and longitude (Table 4). Regressions also were run with mean annual precipitation included in order to determine whether dilution-enrichment effects could contribute to, or mask, spatial trends.

For several ions, the concentrations show a more than twofold increase from east to west within the region (Figs. 11, 12, and 13). For $\mathrm{NO}_{3}{ }^{-}, \mathrm{SO}_{4}{ }^{2-}, \mathrm{H}^{+}, \mathrm{Ca}^{2+}$ and $\mathrm{K}^{+}$the regional trends observed are best described as functions of longitude alone. Including latitude in the analyses did not significantly improve any of the relationships. Latitude is, however, a significant predictor for $\mathrm{NH}_{4}{ }^{+}$, resulting in an increase in $\mathrm{NH}_{4}{ }^{+}$ concentration from the southeast to the northwest within the region (Table 4).

Concentrations of $\mathrm{Na}^{+}, \mathrm{Cl}^{-}, \mathrm{Mg}^{2+}$ and $\mathrm{K}^{+}$were between two and five times higher at two coastal sites (North Atlantic Coastal Lab, Barnstable, Massachusetts, and Acadia National Park, Maine) than at sites only slightly further inland, presumably due to inputs from sea spray. These data were omitted from the regressions. For $\mathrm{Na}^{+}$and $\mathrm{Cl}^{-}$, the remaining data show an exponential decrease in concentration with increasing distance from the ocean; this decrease can be approximated by regressing log-transformed concentration values on latitude and longitude (Table 4). The resulting equations do not account for the local increases expected immediately adjacent to the seacoast, but do fit existing data for inland sites better than regressions that include the coastal sites. Magnesium concentrations also decreased with distance from the ocean, but the trend is weaker and is best fit as a linear function of latitude and longitude.

In order to generate spatial coverages of wet deposition, these concentration trends are combined with a digital

Table 4. - Regression coefficients and statistics for ion concentrations in precipitation. Coefficients are significant to $p<$ 0.05 except the longitude $\mathbf{M g}^{2+}$ coefficient for which $\mathbf{p}<0.10$. Standard errors are in parentheses. Number of values $=$ 26 except regressions marked * had two coastal sites omitted. Means for $\mathrm{Na}^{+}$and $\mathrm{Cl}^{-}$are from untransformed values.

\begin{tabular}{|c|c|c|c|c|c|c|c|}
\hline Ion & \multicolumn{3}{|c|}{ Coefficients (S.E.) } & Mean & Adj. $R^{2}$ & Root MSE & $p$ \\
\hline & $m g / L$ & $(m g / L) / d e g$ & $(m g / L) / d e g$ & $m g / L$ & & $m g / L$ & \\
\hline $\mathrm{SO}_{4}^{2-}$ & $\begin{array}{c}-9.5871 \\
(1.06)\end{array}$ & $\begin{array}{l}0.1612 \\
(0.01)\end{array}$ & & 2.27 & 0.83 & 0.237 & $<0.0001$ \\
\hline $\mathrm{NH}_{4}^{+}$ & $\begin{array}{c}-2.4359 \\
(0.43)\end{array}$ & $\begin{array}{c}0.0259 \\
(0.003)\end{array}$ & $\begin{array}{c}0.0172 \\
(0.006)\end{array}$ & 0.209 & 0.78 & 0.036 & $<0.0001$ \\
\hline $\mathrm{H}^{+}$ & $\begin{array}{c}-0.2205 \\
(0.02)\end{array}$ & $\begin{array}{c}0.0036 \\
(0.0003)\end{array}$ & & 0.047 & 0.84 & 0.005 & $<0.0001$ \\
\hline${ }^{\star} \mathrm{K}^{+}$ & $\begin{array}{c}-0.0439 \\
(0.02)\end{array}$ & $\begin{array}{c}0.0009 \\
(0.0006)\end{array}$ & & 0.021 & 0.21 & 0.005 & 0.01 \\
\hline${ }^{*} \mathrm{Mg}^{2+}$ & $\begin{array}{l}0.3488 \\
(0.05)\end{array}$ & $\begin{array}{c}-0.0017 \\
(0.001)\end{array}$ & $\begin{array}{c}-0.0046 \\
(0.002)\end{array}$ & 0.029 & 0.24 & 0.009 & 0.02 \\
\hline${ }^{*} \ln \mathrm{Na}^{+}$ & $\begin{array}{c}26.4011 \\
(4.91)\end{array}$ & $\begin{array}{c}-0.1932 \\
(0.04)\end{array}$ & $\begin{array}{c}-0.3372 \\
(0.06)\end{array}$ & 0.185 & 0.58 & 0.335 & $<0.0001$ \\
\hline${ }^{*} \ln \mathrm{Cl}^{-}$ & $\begin{array}{c}24.8873 \\
(4.90)\end{array}$ & $\begin{array}{c}-0.1604 \\
(0.04)\end{array}$ & $\begin{array}{c}-0.3427 \\
(0.06)\end{array}$ & 0.350 & 0.56 & 0.355 & $<0.0001$ \\
\hline
\end{tabular}



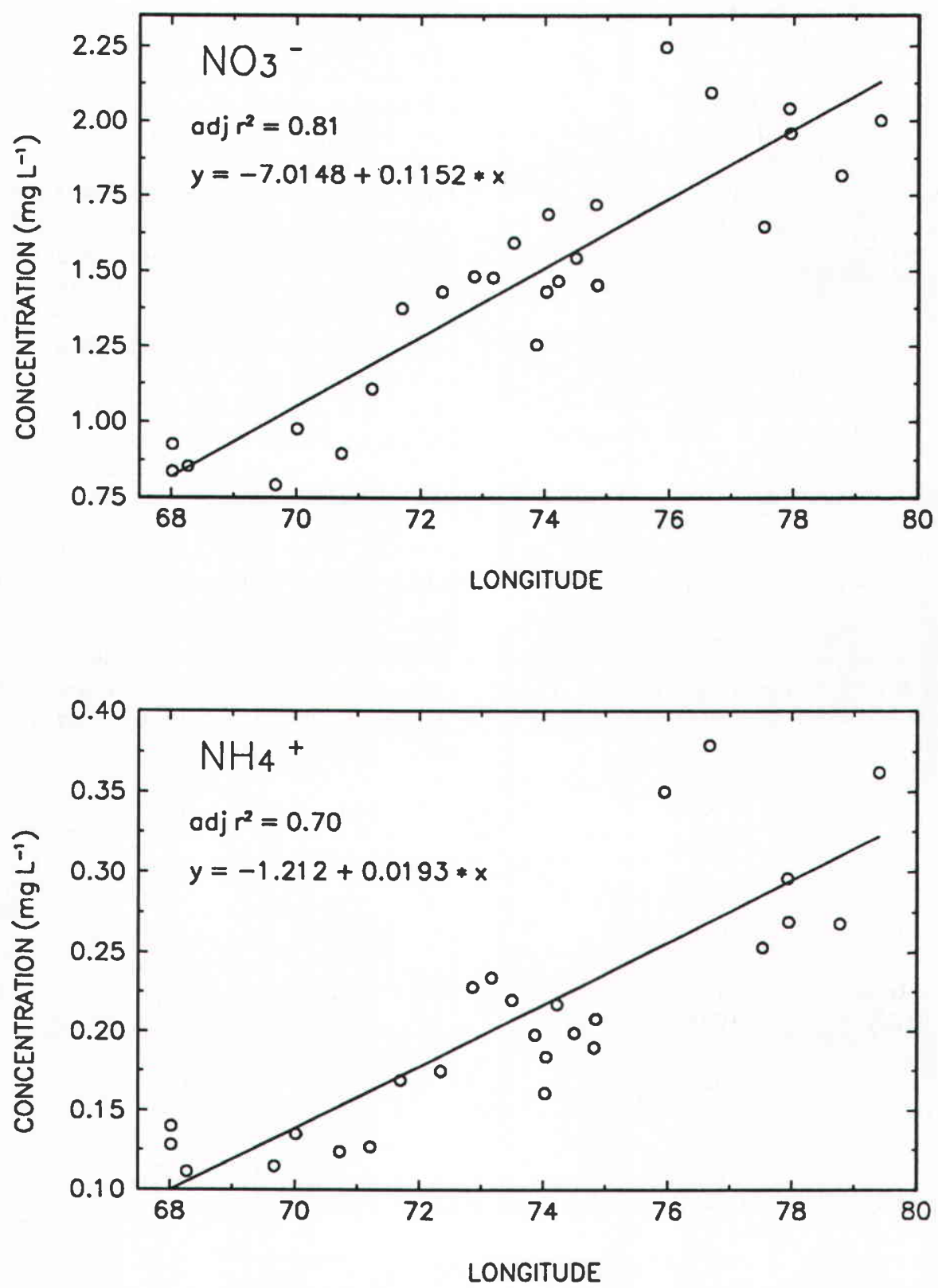

Figure 11. - Regional trends in mean annual concentrations of $\mathrm{NO}_{3}{ }^{-}$and $\mathrm{NH}_{4}{ }^{+}$in precipitation. A slight latitude trend also is present in the $\mathrm{NH}_{4}{ }^{+}$data (Table 1). 

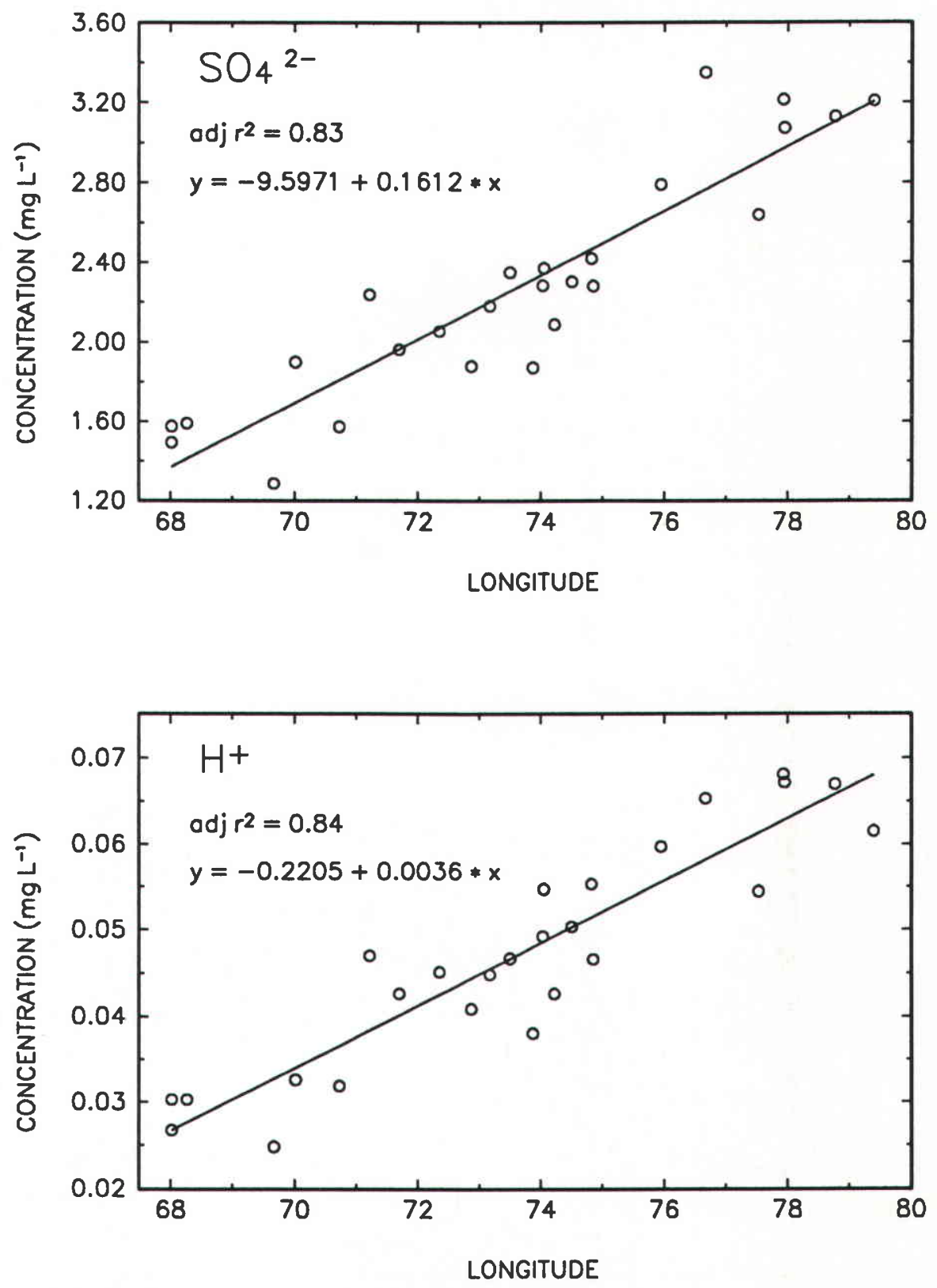

Figure 12. - Regional trends in mean annual concentrations of $\mathrm{SO}_{4}{ }^{2-}$ and $\mathrm{H}^{+}$in precipitation. 

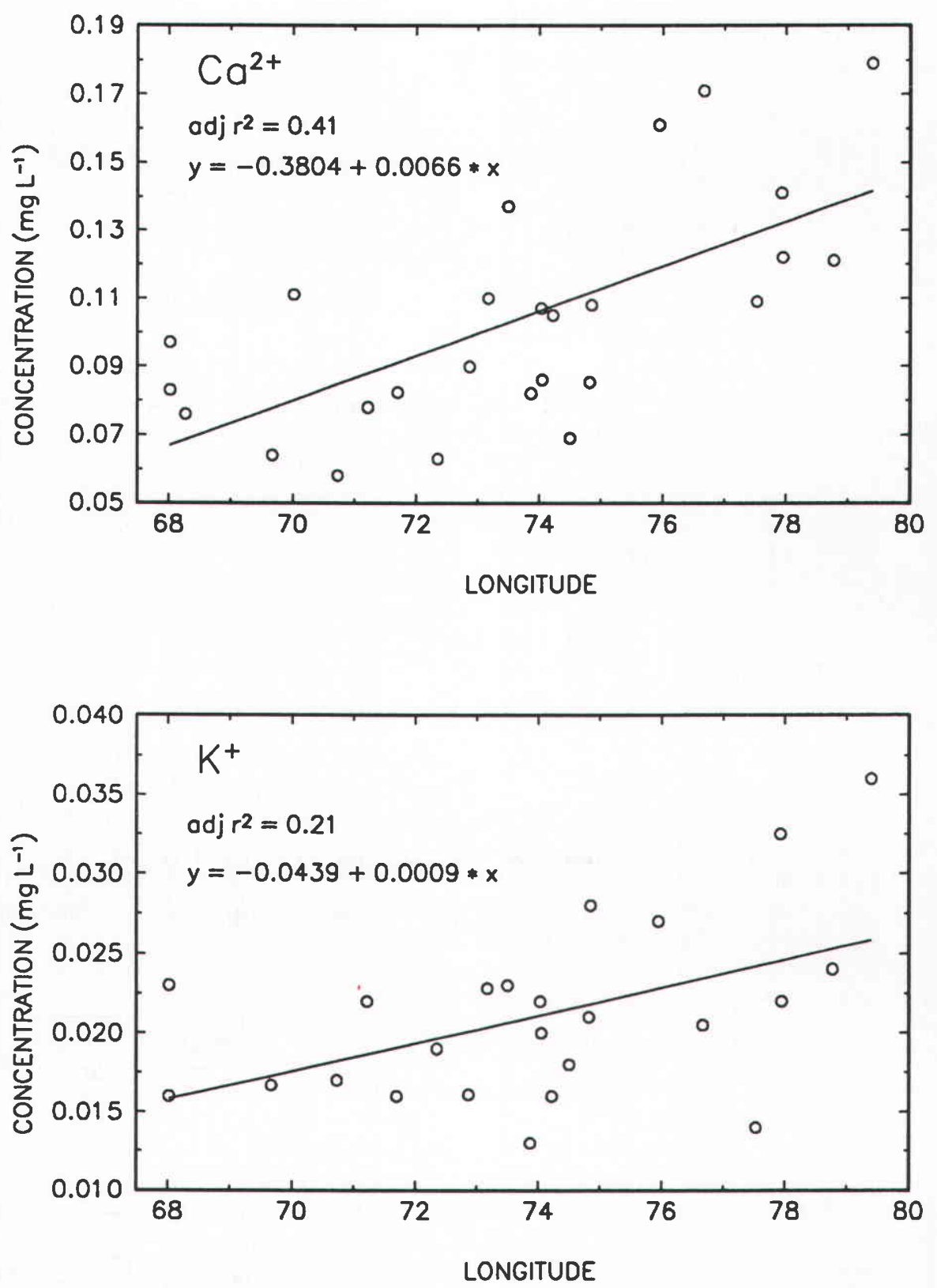

Figure 13. - Regional trends in mean annual concentrations of $\mathrm{Ca}^{2+}$ and $\mathrm{K}^{+}$in precipitation. 
coverage of annual precipitation, obtained from the monthly coverages discussed previously. This improves the resolution of predictions over using data from the deposition monitoring sites alone both by including regional precipitation trends and by providing a means of estimating increases in wet deposition with elevation. We have assumed that there are no elevational trends in ion concentration. The few relevant studies that have been conducted support this assumption (TVA 1983; Scherbatskoy and Bliss 1984; Lindberg et al. 1988; Miller et al. 1993).

Wet deposition of nitrogen $\left(\mathrm{NO}_{3}{ }^{-}+\mathrm{NH}_{4}{ }^{+}\right)$at low elevations is predicted to range from approximately $6.6 \mathrm{~kg} \mathrm{ha}^{-1} \mathrm{yr}^{-1}$ in western New York to $3.0 \mathrm{~kg} \mathrm{ha}^{-1} \mathrm{yr}^{-1}$ in eastern Maine. Predicted wet sulfur deposition ranges from 9.4 to $4.3 \mathrm{~kg} \mathrm{ha}^{-1} \mathrm{yr}^{-1}$ across the same gradient. With elevational increases in precipitation (Table 2), predicted wet deposition of $\mathrm{N}$ and $\mathrm{S}$ to high elevation sites can be nearly twice that received by adjacent low elevation sites.

In addition to the spatial trends in ion concentrations discussed above, $\mathrm{SO}_{4}{ }^{2-}$ and several other ions have decreased in concentration through time over the last decade (Hedin et al. 1987, Driscoll and Van Dreason, 1993). Although there is no relationship within the NADP/NTN data set between the time periods of data collection and the location of collection sites (indicating that the spatial trends observed are independent of temporal trends), the equations in Table 4 do not account for temporal trends, and apply approximately to an average year within the data record. This does not greatly affect current estimates, but future projections could be substantially offset if these temporal trends continue.

To evaluate the effects of temporal trends within the NADP/ NTN data set, we performed latitude-longitude regressions using yearly concentration data rather than long-term average concentrations, and included time of data collection as an additional variable. This approach does not replace conducting time series analyses for each collection site, but does allow temporal trends to be integrated across the entire study area.

For the ions $\mathrm{SO}_{4}{ }^{2-}, \mathrm{Ca}^{2+}, \mathrm{Mg}^{2+}$ and $\mathrm{K}^{+}$, collection time was significant at $p<0.05$. Coefficients showing rates of decline in concentration for these ions (in $\mathrm{mg} \mathrm{l}^{-1} \mathrm{yr}^{-1}$ ) are $0.0305,0.0054$, 0.0059 and 0.0009 , respectively. Temporal trends for these four ions from 1980 through 1989 are shown in Figure 14. No other ion, including hydrogen, showed any significant change over the period of data collection.

\section{Dry Deposition}

Due to the difficulties associated with measuring dry deposition fluxes to complex surfaces, few reliable dry deposition data exist. As an alternative, we use an inferential method whereby atmospheric concentrations of dry-deposited species are combined with estimates of deposition velocities in order to estimate dry deposition amounts.

Data on atmospheric concentrations of the gases $\mathrm{SO}_{2}$ and $\mathrm{HNO}_{3}$ and the aerosol species $\mathrm{NO}_{3}{ }^{-}, \mathrm{SO}_{4}{ }^{2-}$, and $\mathrm{NH}_{4}{ }^{+}$were obtained from several sources. Annual mean data for 11 sites in New England, New York, Pennsylvania, and New Jersey for 1989 and 1990 were obtained from the National Dry Deposition Network (NDDN) sponsored by the Environmental Protection Agency (Edgerton et al. 1991; Edgerton and Lavery 1991). Two other sites that obtained data using the same methods were included: the Huntington Forest site in the eastern Adirondacks (1986-1988 mean concentrations reported by Johnson and Lindberg 1992), and the Institute of Ecosystem Studies site in southeastern New York (19881990 mean concentrations, IES 1988, 1989, 1990). We evaluated regional trends of air concentrations by regression analysis of mean annual concentrations against latitude and longitude. The density of sites is not sufficient to resolve any elevation effects.

In contrast to precipitation chemistry, atmospheric concentrations vary to a greater extent with latitude than with longitude within the region (Figs. 15, 16). With the exception of aerosol $\mathrm{NO}_{3}{ }^{-}$(not shown), the latitude coefficient was highly significant in all the regressions, but longitude was significant at the $p<$ 0.05 level only for $\mathrm{SO}_{2}$ (Table 5). Longitude was significant at the $\mathrm{p}<0.1$ level for $\mathrm{SO}_{4}{ }^{2-}$, and its inclusion improved the regression $\mathrm{R}^{2}$ value, so it was retained in the final equation.

The latitude coefficients are consistently negative, indicating that concentrations decrease from south to north. The longitude coefficients for $\mathrm{SO}_{2}$ and $\mathrm{SO}_{4}{ }^{2-}$ are positive, corresponding to an increase in concentrations from east to west. Across the study area, the magnitude of the latitude effect is stronger than the longitude effect for $\mathrm{SO}_{2}$, while the two effects are more nearly equal for $\mathrm{SO}_{4}{ }^{2-}$. For $\mathrm{HNO}_{3}$ and $\mathrm{NH}_{4}{ }^{+}$, the longitude coefficients were not significant and only latitude is used in the predictions.

To calculate dry deposition fluxes from atmospheric concentrations, dry deposition velocities must be specified. Deposition velocities are difficult to measure and are variable in magnitude, depending on the nature of the depositing substance, the deposition surface, and meteorological factors. Within the northeastern United States the factors most likely to cause changes in dry deposition are the vegetation cover present, meteorological conditions, and atmospheric concentrations. If we restrict our predictions to deciduous forests and assume that average meteorological conditions (for example, wind speed) do not vary substantially across the region, the patterns in atmospheric concentrations will reflect patterns of dry deposition. This assumption is supported by Edgerton and Lavery (1991) who calculated that changes in deposition of $\mathrm{SO}_{2}$ across the eastern United States are influenced to a much greater extent by concentration differences than by differences in deposition velocity.

We use deposition velocity estimates representative of a deciduous forest (averaging growing and dormant season values for an annual mean, in $\mathrm{cm} \mathrm{s}^{-1}$ ) of 1.3 for $\mathrm{HNO}_{3}$ and 0.13 for aerosol $\mathrm{SO}_{4}{ }^{2-}, \mathrm{NO}_{3}{ }^{-}$and $\mathrm{NH}_{4}{ }^{+}$(Lindberg et al. 1986). For $\mathrm{SO}_{2}$, we chose a deposition velocity of 0.22 by taking the average of values calculated by Edgerton and Lavery (1991) for several sites across the region. These are our best estimates of the dry deposition velocities, but they may be inaccurate by as much as a factor of 2 . 

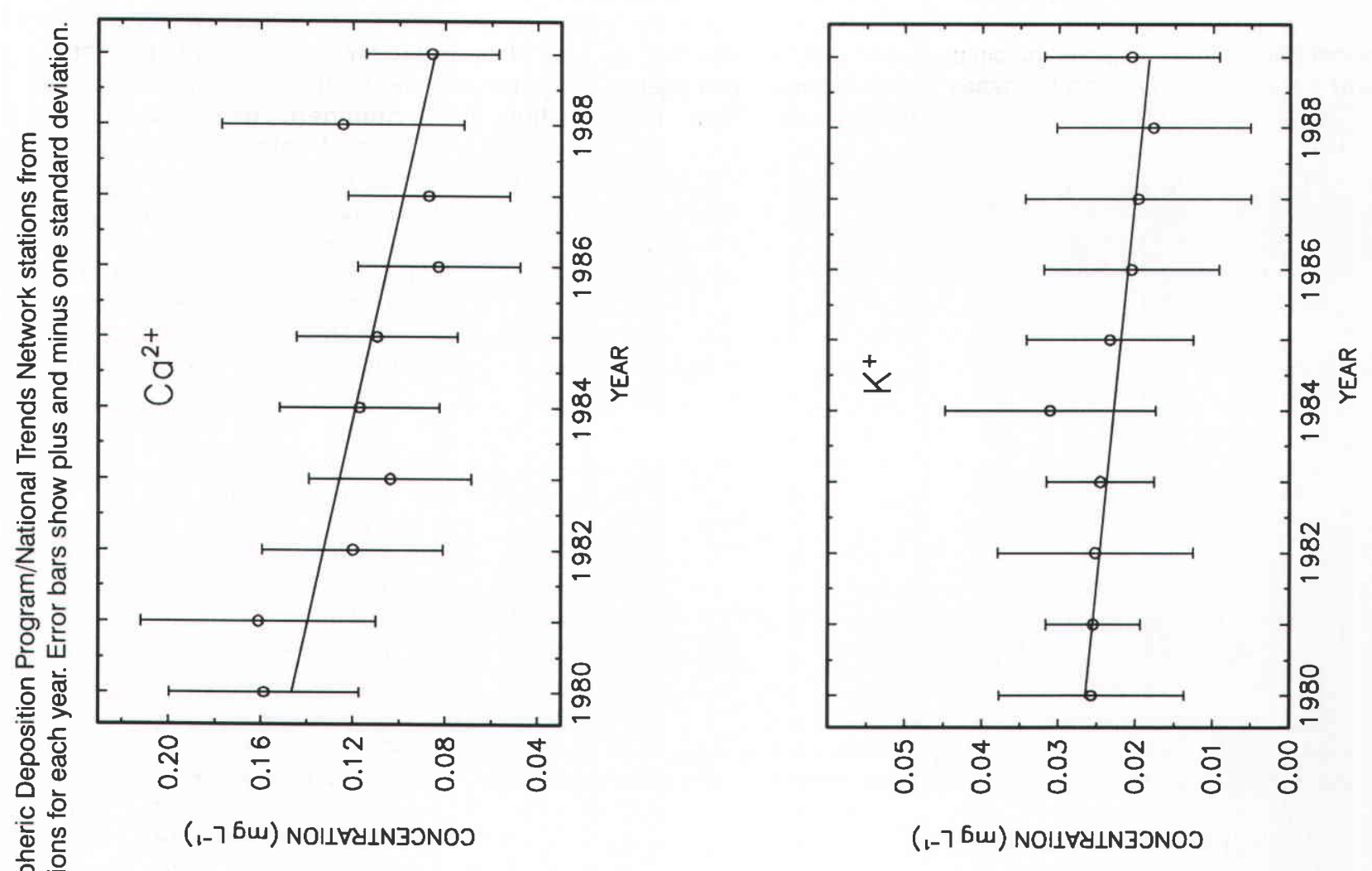

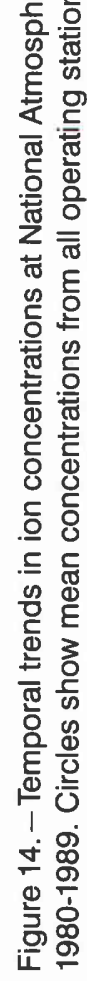

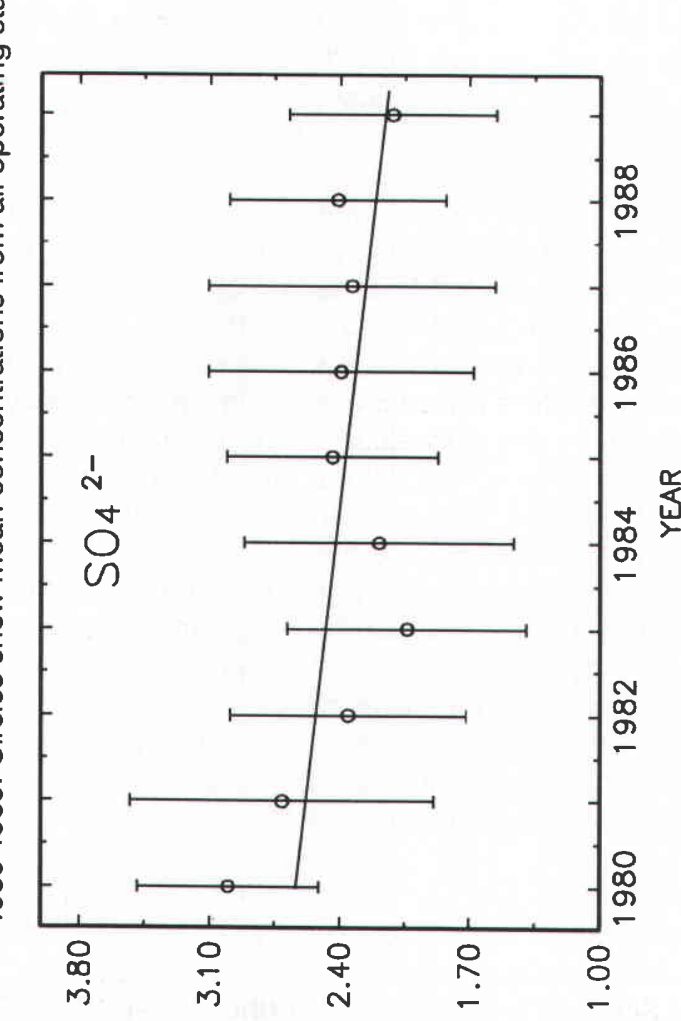

$(1-76 w)$ NOIIVYINJJNOJ

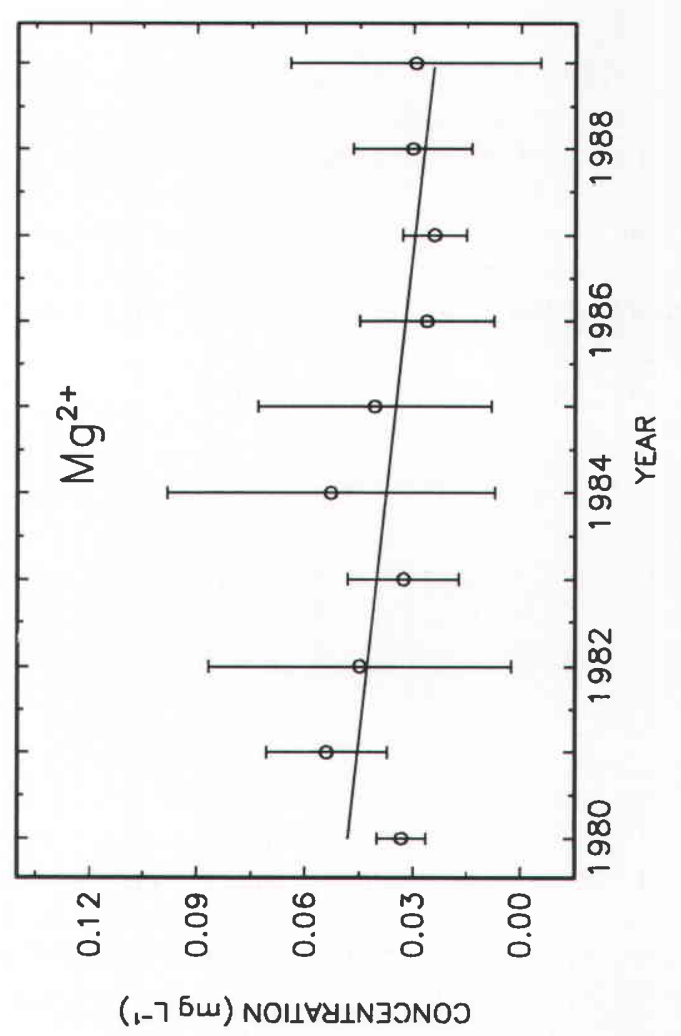



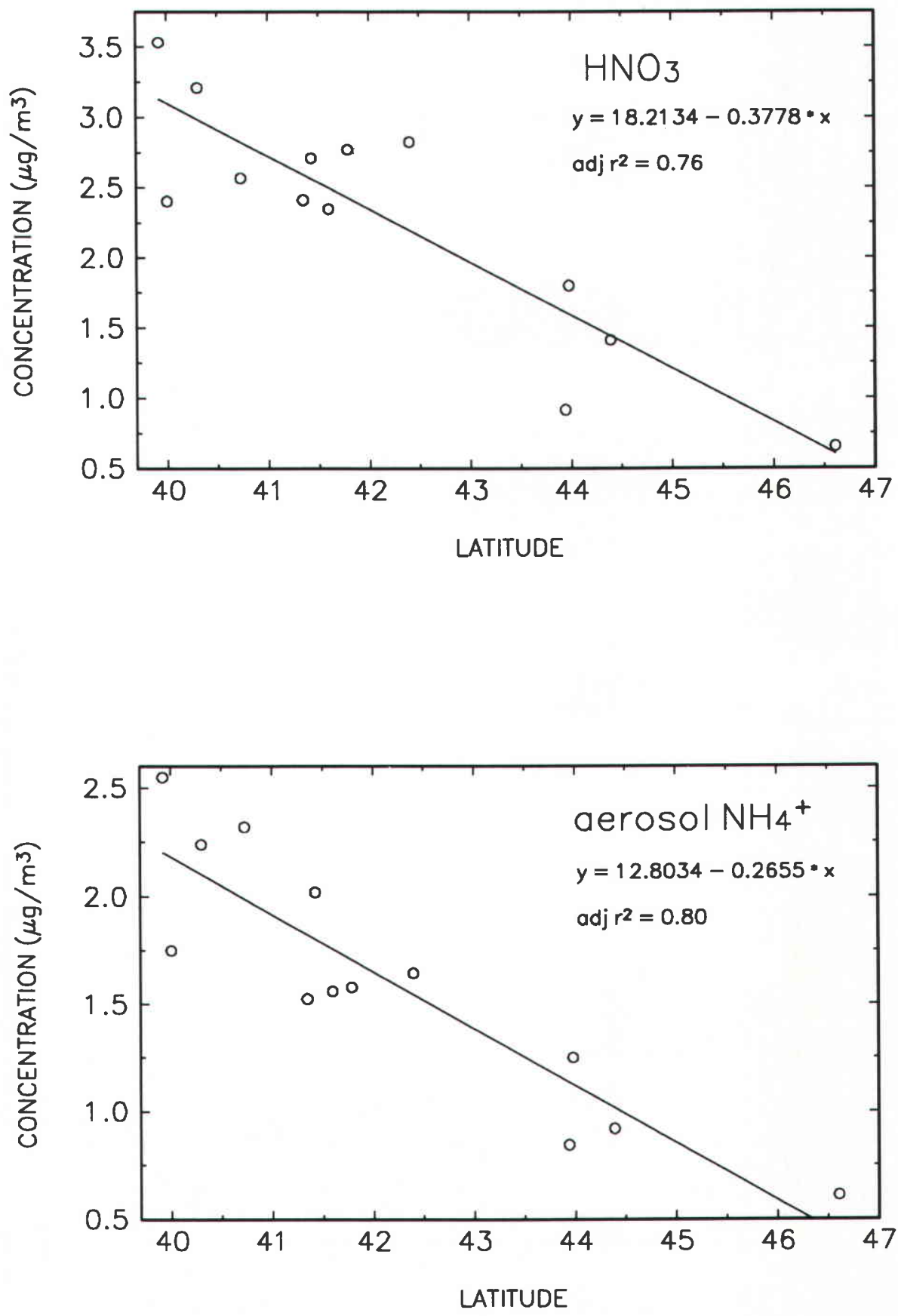

Figure 15. - Regional trends in mean annual air concentrations of $\mathrm{HNO}_{3}$ and aerosol $\mathrm{NH}_{4}{ }^{+}$. No trend was observed for aerosol $\mathrm{NO}_{3}{ }^{-}$, which is not shown. 

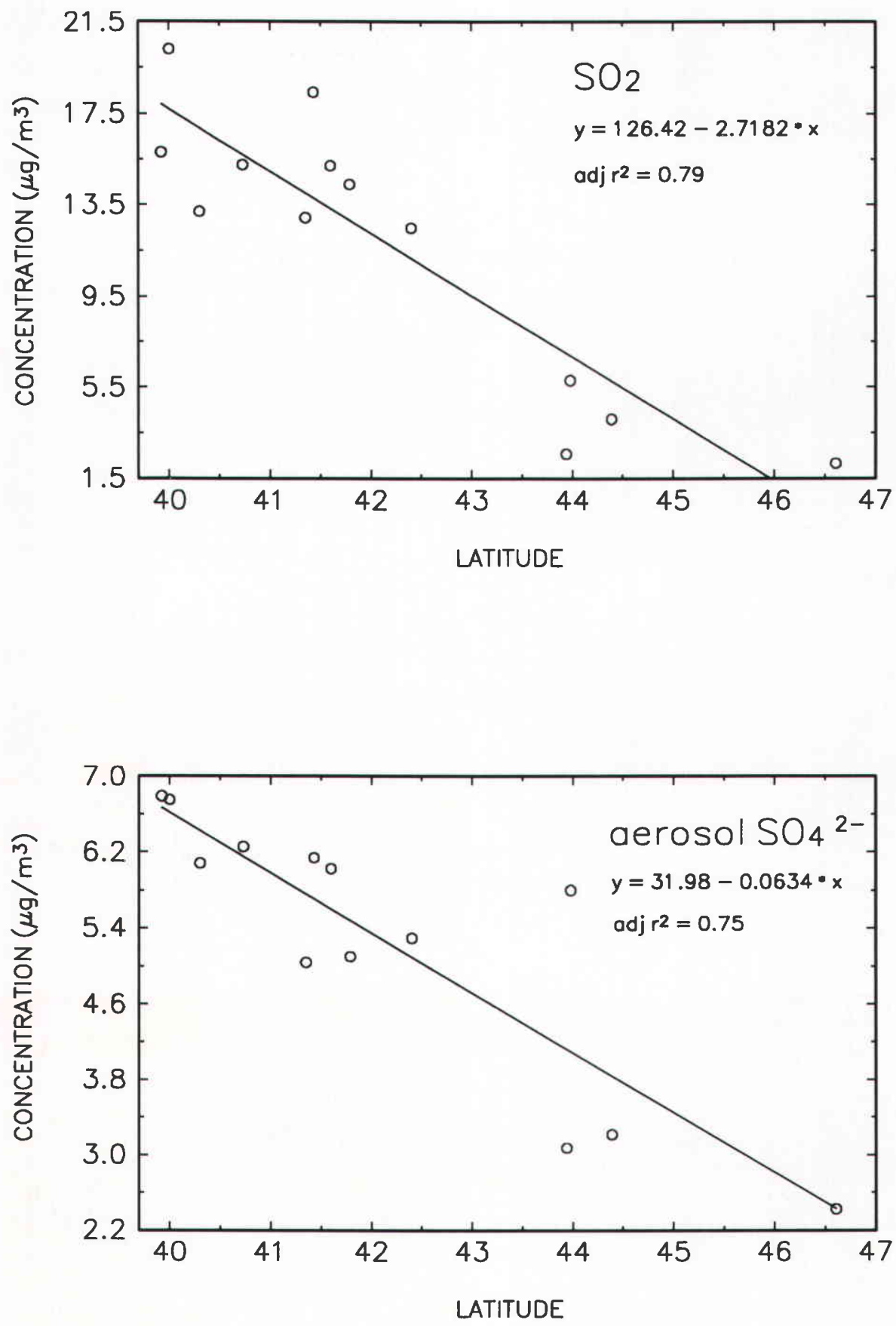

Figure 16. - Dominant regional trends in mean annual air concentrations of $\mathrm{SO}_{2}$ and aerosol $\mathrm{SO}_{4}{ }^{2-}$. Longitude also is a significant predictor for these substances (Table 5). 


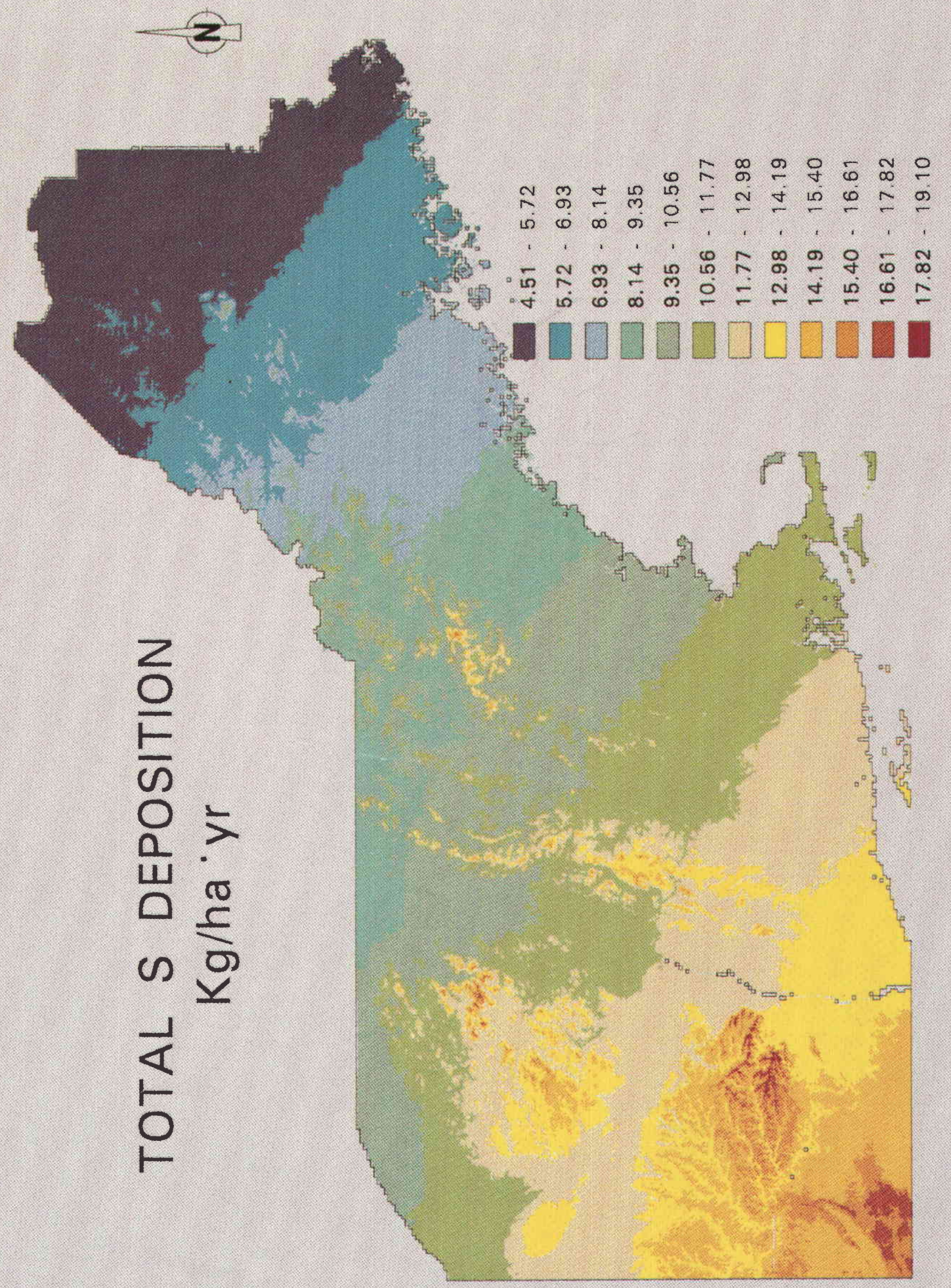




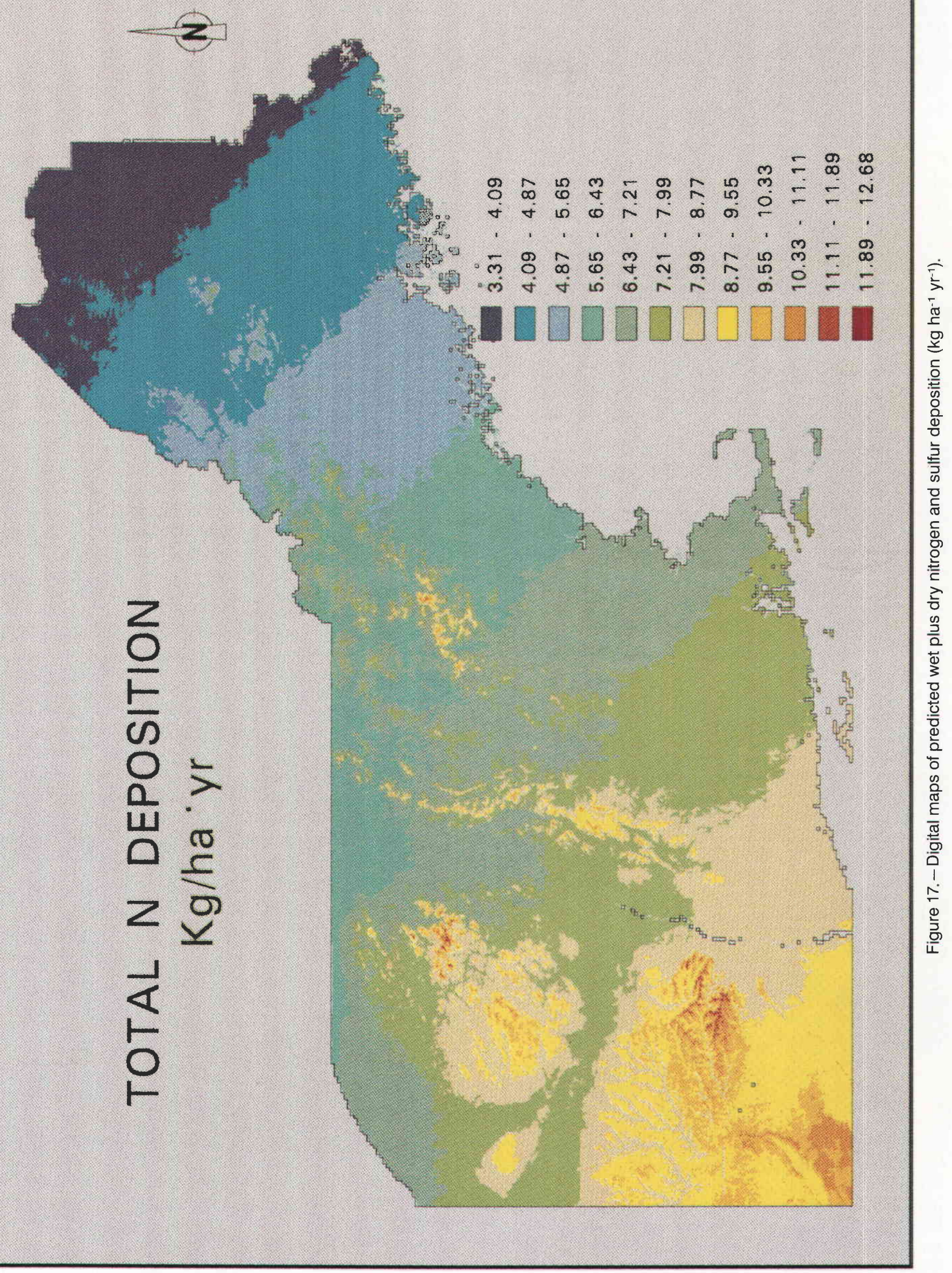


Table 5.-Regression coefficients and statistics for air concentrations of dry deposited species. Coefficients are significant to $\mathrm{p}<0.05$ except the longitude $\mathrm{SO}_{4}{ }^{2-}$ coefficient, for which $\mathrm{p}<0.10$. Standard errors are in parentheses. Number of values $=13$.

\begin{tabular}{|c|c|c|c|c|c|c|c|}
\hline \multirow{2}{*}{$\begin{array}{l}\text { Chemical } \\
\text { Species }\end{array}$} & \multicolumn{3}{|c|}{ Coefficients (S.E.) } & \multirow[b]{2}{*}{ Mean } & \multirow[b]{2}{*}{ Adj. $\mathrm{R}^{2}$} & \multirow[b]{2}{*}{ Root MSE } & \multirow[b]{2}{*}{$p$} \\
\hline & Constant & Latitude & Longitude & & & & \\
\hline & $\left(\mu g / m^{3}\right) / d e g$ & $\left(\mu g / m^{3}\right) / d e g$ & $\left(\mu g / m^{3}\right) / d e g$ & $\mu g / m^{3}$ & & $\mu g / m^{3}$ & \\
\hline $\mathrm{SO}_{2}$ & $\begin{array}{c}9.5814 \\
(44.74)\end{array}$ & $\begin{array}{c}-1.7584 \\
(0.54)\end{array}$ & $\begin{array}{l}0.7468 \\
(0.32)\end{array}$ & 11.75 & 0.85 & 2.36 & $<0.0001$ \\
\hline $\begin{array}{l}\text { Aerosol } \\
\mathrm{SO}_{4}{ }^{2-}\end{array}$ & $\begin{array}{c}8.6311 \\
(11.91)\end{array}$ & $\begin{array}{c}-0.4027 \\
(0.14)\end{array}$ & $\begin{array}{l}0.1801 \\
(0.09)\end{array}$ & 5.23 & 0.81 & 0.63 & 0.0001 \\
\hline $\begin{array}{l}\mathrm{HNO}_{3} \\
\text { vapor }\end{array}$ & $\begin{array}{l}18.2134 \\
(2.53)\end{array}$ & $\begin{array}{c}-0.3778 \\
(0.06)\end{array}$ & & 2.27 & 0.76 & 0.42 & 0.0001 \\
\hline $\begin{array}{l}\text { Aerosol } \\
\mathrm{NO}_{3}^{-}\end{array}$ & $\begin{array}{c}0.75 \\
(0.13)\end{array}$ & & & 0.75 & & 0.48 & \\
\hline $\begin{array}{l}\text { Aerosol } \\
\mathrm{NH}_{4}{ }^{+}\end{array}$ & $\begin{array}{l}12.8035 \\
(1.62)\end{array}$ & $\begin{array}{c}-0.2655 \\
(0.04)\end{array}$ & & 1.60 & 0.80 & 0.27 & $<0.0001$ \\
\hline
\end{tabular}

Dry deposition estimates are generated by combining the air concentration trends (Table 5) with the above deposition velocities for all species except aerosol $\mathrm{NO}_{3}-$. Because aerosol $\mathrm{NO}_{3}$ - concentrations did not show significant trends with latitude or longitude, the regional mean value $\left(0.75 \mu \mathrm{g} \mathrm{m}^{-3}\right)$ was used for all locations. In most cases, aerosol $\mathrm{NO}_{3}{ }^{-}$contributed less than 10 percent of the total dry $\mathrm{N}$ deposition. Confidence in the resulting predictions is limited by the uncertainty surrounding the deposition velocities, which again, are applied only to a "typical" deciduous forest, and are assumed to remain constant across the region. In addition, too little information exists to address elevational trends in dry deposition, although some increase in dry deposition with elevation might be expected (Lovett and Kinsman 1990).

Predicted dry deposition of $S$ varies from $7.5 \mathrm{~kg} \mathrm{ha}^{-1} \mathrm{yr}^{-1}$ in southwestern Pennsylvania ( 88 percent as $\mathrm{SO}_{2}$ ) to only 0.27 $\mathrm{kg} \mathrm{ha}^{-1} \mathrm{yr}^{-1}$ in northern Maine (0 percent as $\mathrm{SO}_{2}$ ), principally because of the strong gradient in $\mathrm{SO}_{2}$ concentration. Predicted dry deposition of $S$ is slightly greater than wet deposition in southwestern Pennsylvania, but is only 7 percent of wet deposition in northern Maine.

Total dry $\mathrm{N}$ deposition also varies substantially, from $3.6 \mathrm{~kg}$ $\mathrm{ha}^{-1} \mathrm{yr}^{-1}$ in the southwest (78 percent as $\mathrm{HNO}_{3}, 2$ percent as $\mathrm{NO}_{3}{ }^{-}$and 20 percent as $\left.\mathrm{NH}_{4}{ }^{+}\right)$to $2.2 \mathrm{~kg} \mathrm{ha}^{-1} \mathrm{yr}^{-1}$ in the northeast (71 percent as $\mathrm{HNO}_{3}, 12$ percent as $\mathrm{NO}_{3}{ }^{-}$and 17 percent as $\left.\mathrm{NH}_{4}{ }^{+}\right)$. Predicted dry $\mathrm{N}$ deposition is 46 percent of wet deposition in southwestern Pennsylvania and 20 percent of wet deposition in northern Maine.

\section{Total Deposition}

Combining the east-west wet deposition gradients of $\mathrm{N}$ and $\mathrm{S}$ compounds with the predominantly north-south dry deposition gradients produces trends of decreasing total deposition from the southwest to the northeast within the region. Predicted total deposition of sulfur decreases from about $19 \mathrm{~kg} \mathrm{~S}$ $\mathrm{ha}^{-1} \mathrm{yr}^{-1}$ in southwestern Pennsylvania $(40 \mathrm{~N}, 80 \mathrm{~W}, 300 \mathrm{~m}$ elevation) to less than $5 \mathrm{~kg} \mathrm{~S} \mathrm{ha}^{-1} \mathrm{yr}^{-1}$ in northern Maine $(46 \mathrm{~N}$, $69 \mathrm{~W}, 300 \mathrm{~m}$ ) (Fig. 17). Predicted total nitrogen deposition decreases from approximately $11.5 \mathrm{~kg} \mathrm{~N} \mathrm{ha}^{-1} \mathrm{yr}^{-1}$ to less than 4 $\mathrm{kg} \mathrm{N} \mathrm{ha}^{-1} \mathrm{yr}^{-1}$ along the same gradient (Fig. 17). Elevational increases in deposition predictions are driven only by increases in predicted precipitation. We did not attempt to include cloud water deposition although cloud water can contribute substantial inputs to high elevation sites (Lovett and Kinsman 1990).

It also should be noted that the measurement sites from which air and precipitation chemistry are available are located in rural areas to avoid local enhancement of atmospheric deposition from cities and other large pollution sources. Although such sources exist within the study region, especially in southern and coastal areas, their local effects are not accounted for in the deposition patterns shown here because necessary data are not available to quantify them. A particularly important example of this problem is nitrogen dioxide $\left(\mathrm{NO}_{2}\right)$, which may cause large increases in $\mathrm{N}$ deposition near urban areas (Hanson et al., 1989), but is not measured at the air concentration monitoring sites used in this study.

\section{Conclusion}

Many environmental factors that influence terrestrial ecosystems vary greatly across space and time. This variation must be accounted for in order to apply ecosystem modeling successfully to landscape and regional scales, especially in evaluating effects of large-scale disturbance or global change.

Because geographic information systems are designed to allow spatial data to be stored and manipulated, they can provide a useful environment in which to link ecosystem models with driving climate variables. In this report, we have identified patterns of several physical and chemical climate variables across the northeastern United States that have potentially important effects on the function of forest ecosystems across the region. We also have demonstrated how 
those patterns can be used to generate spatially explicit coverages within a GIS.

The climate variables we have discussed are those required by a model of forest productivity and hydrology (PnET, Aber and Federer 1992), and were not previously available in digital form. The methods used to evaluate and quantify spatial trends were chosen with consideration of the limitations of available data bases, the nature of spatial variability observed and degree to which it influences regional productivity, and the ease with which predictions can be combined with ecosystem models. In regions with different physiographic and climatic variability, other methods may be more appropriate.

Linking ecosystem models with geographic information systems can provide a powerful tool for assessing the spatial variability of important ecosystem properties and projecting future effects of human impacts across real landscapes. Making this link requires that spatial coverages of important environmental parameters be created from available data bases. Decisions on how to perform this task may involve tradeoffs, and should be made with consideration of both the nature of the climatic variability encountered and the compatibility of resulting predictions with ecosystem models. With these decisions properly made, the modeling-GIS link can help bring ecosystem science from the plot level to scales at which elements of environmental change act.

\section{References}

Aber, J.D.; Driscoll, C.; Federer, C.A.; Lathrop, R.; Lovett, G.; Melillo, J.M.; Steudler, P.; Vogelmann, J. 1993. A strategy for the regional analysis of the effects of physical and chemical climate change on biogeochemical cycles in northeastern (U.S.) forests. Ecological Modeling. 67: 37-47.

Aber, J.D.; Federer, C.A. 1992. A generalized, lumpedparameter model of photosynthesis, evapotranspiration and net primary production in temperate and boreal forest ecosystems. Oecologia. 92: 463-474.

Burke, I.C.; Schimel, D.S.; Yonker, C.M.; Parton, W.J.; Joyce, L.A.; Lauenroth, W.K. 1990. Regional modeling of grassland biogeochemistry using GIS. Landscape Ecology. 4: 45-54.

Dingman, S.L. 1981. Elevation: a major influence on the hydrology of New Hampshire and Vermont, USA. Hydrological Sclences Bulletin. 26: 399-413.

Dingman, S.L.; Seely-Reynolds, D.M.; Reynolds III, R.C. 1988. Application of kriging to estimating mean annual precipitation in a region of orographic influence. Water Resources Bulletin. 24: 329-339.

Driscoll, C.T.; Van Dreason, R. 1993. Seasonal and long-term patterns in the chemistry of Adirondack lakes. Water, Air and Soil Pollution. 67: 319-334.

Edgerton, E.S.; Lavery, T.F. 1991. National dry deposition network: fourth annual progress report (1990). Research Triangle Park, NC: U.S. Environmental Protection Agency. Report of contract no. 68-02-4451.
Edgerton, E.S.; Lavery, T.F.; Prentice, H.S. 1991. National dry deposition network: third annual progress report (1989). Washington, DC: U.S. Environmental Protection Agency, Office of Research and Development. EPA/600/3-91/018.

Environmental Data Service. 1968. Climatic atlas of the United States. U.S. Department of Commerce. Environmental Services Administration. 80 p.

Environmental Data Service. 1955-1972. Climatological data, national summary, annual. U.S. Department of Commerce. Environmental Services Administration.

Environmental Systems Research Institute. 1992. Cell-based modeling with GRID. Environmental Systems Research Institute. Redlands, CA.

Federer, C.A.; Flynn, L.D.; Martin, C.W.; Hornbeck, J.W.; Pierce, R.S. 1990. Thirty years of hydrometeorologic data at the Hubbard Brook Experimental Forest, New Hampshire. Gen. Tech. Rep. NE-141. Radnor PA: U.S. Department of Agriculture, Forest Service, Northeastern Forest Experiment Station, $44 \mathrm{p}$.

Gentilli, J. 1955. Estimating dewpoint from minimum temperature. Bulletin of the American Meteorological Society. 36: 128-131.

Hanson, P.J.; Rott, K.; Taylor, G.E., Gunderson, C.A.; Lindberg, S.E.; Ross-Todd, B.M. 1989. $\mathrm{NO}_{2}$ deposition to elements representative of a forest landscape. Atmospheric Environment. 23: 1783-1794.

Hedin, L.O.; Likens, G.E.; Bormann, F.H. 1987. Decrease in precipitation acidity resulting from decreased $\mathrm{SO}_{4}{ }^{2-}$ concentration. Nature. 325: 244-246.

Institute of Ecosystem Studies. 1988-1990. Annual air quality report: 1988-1990. Millbrook, NY: Institute of Ecosystem Studies.

Johnson, D.W.; Lindberg, S.E., eds. 1992. Atmospheric deposition and nutrient cycling in forest ecosystems. New York: Springer-Verlag. 707 p.

Lindberg, S.E.; Lovett, G.M.; Richter, D.D.; Johnson, D.W. 1986. Atmospheric deposition and canopy interactions of major ions in a forest. Science. 231: 93-102.

Lindberg, S.E.; Silsbee, D.; Schaefer, D.A.; Owens, J.G.; Petty, W. 1988. A comparison of atmospheric exposure conditions at high- and low-elevation forests in the southern Appalachian Mountain Range. In: Unsworth, M.H.; Fowler, D., eds., Deposition processes at high elevatlon sites. Kluwer, Dordecht: 321-344.

Lovett, G.M.; Kinsman, J.D. 1990. Atmospheric pollutant deposition to high elevation ecosystems. Atmospheric Environment. 24: 2767-2786.

Lydolph, P.E. 1985. Weather and climate. Totowa, NJ: Rowman and Allanheld. 216 p.

Miller, E.K.; Panek, J.A.; Friedland, A.J.; Kadlecek, J.; Mohnen, V.A. 1993. Atmospheric deposition to a high-elevation forest at Whiteface Mountain, New York, USA. Tellus. 45B: $209-227$. 
Murray, F.W. 1967. On the computation of saturation vapor pressure. Journal of Applied Meteorology. 6: 203-204.

National Atmospheric Deposition Program (IR-7)/National Trends Network. 1990. Notes concerning NADP/NTN weighted average reports. Fort Collins, CO: NADP/NTN Coordinating Office, Natural Resource Ecology Laboratory, Colorado State University.

National Atmospheric Deposition Program (IR-7)/National Trends Network. 1991. Fort Collins, CO: NADP/NTN Coordinating Office, Natural Resource Ecology Laboratory, Colorado State University.

National Oceanic and Atmospheric Administration. 1982 Climatography of the United States No. 81 (by state) U.S. Department of Commerce, Asheville, NC: National Oceanic and Atmospheric Administration Environmental Data and Information Service, National Climatic Center.

Ollinger, S.V.; Aber, J.D.; Lovett, G.M., Millham, S.E.; Lathrop, R.G.; Ellis, J.M. 1993. A spatial model of atmospheric deposition for the northeastern U.S. Ecological Applications. 3: 459-472.

Pastor, J.; Post, W.M. 1986. Influence of climate, soil moisture, and succession on forest carbon and nitrogen cycles. Biogeochemistry. 2: 3-27.

Rastetter, E.B.; Ryan, M.G.; Shaver, G.R.; Melillo, J.M.; Nadelhoffer, K.J.; Hobbie, J.E.; Aber, J.D. 1991. A general biogeochemical model describing the responses of the
$\mathbf{C}$ and $\mathbf{N}$ cycles in terrestrial ecosystems to changes in $\mathbf{C O}_{2}$, climate and $\mathbf{N}$ deposition. Tree Physiology. 9:101-126.

Scherbatskoy, T.; Bliss, M. 1984. Occurrence of acid rain and cloudwater in high elevation ecosystems in the Green Mountains, Vermont. In: Samson, P.J., ed. The Meteorology of Acid Deposition, Pittsburgh, PA: Air Pollution Control Association. p. 449-463.

Swift, L.W., Jr. 1976. Algorithm for solar radiation on mountain slopes. Water Resources Research. 12: 108-112.

Tennessee Valley Authority. 1983. Investigations of the cause of fishkills in fish-rearing facilities in Raven Fork watershed. TVA/ONR/WR-83/9. Chattanooga, TN: Tennessee Valley Authority.

United States Department of Agriculture, Soil Conservation Service. 1991. State soil geographic data base (STATSGO): Data user's guide. Misc. Publ. 1492. Fort Worth, TX: U.S. Department of Agriculture, Soil Conservation Service. $88 \mathrm{p}$.

United States Geological Survey. 1986. Land use and land cover digital data from 1:250,000- and 1:100,000-scale maps: Data user's guide 4. Reston, VA: U.S. Department of the Interior, Geological Survey. 8 p.

United States Geological Survey. 1987. Digital elevation models: National Mapping Program technical instructions: data users guide 5. Reston, VA: U.S. Department of the Interior, Geological Survey. 38 p. 
Ollinger, Scott V.; Aber, John D.; Federer, C. Anthony; Lovett, Gary M.; Ellis, Jennifer M. 1995. Modeling physical and chemical climate of the northeastern United States for a geographic information system. Gen. Tech. Rep. NE-191. Radnor, PA: U.S. Department of Agriculture, Forest Service, Northeastern Forest Experiment Station. $30 \mathrm{p}$.

A model of physical and chemical climate was developed for New York and New England that can be used in a GIS for integration with ecosystem models. The variables included are monthly average maximum and minimum daily temperatures, precipitation, humidity, and solar radiation, as well as annual atmospheric deposition of sulfur and nitrogen. Equations generated from regional data bases were combined with a digital elevation model of the region to generate digital coverages of each variable.

Keywords: temperature; precipitation; solar radiation; humidity; atmospheric deposition; sulfur; nitrogen

Send requests for publications to:

USDA Forest Service

Publications Distribution

359 Main Road

Delaware, $\mathrm{OH} 43015$ 
Headquarters of the Northeastern Forest Experiment Station is in Radnor, Pennsylvania. Field laboratories are maintained at:

Amherst, Massachusetts, in cooperation with the University of Massachusetts

Burlington, Vermont, in cooperation with the University of Vermont

Delaware, Ohio

Durham, New Hampshire, in cooperation with the University of New Hampshire

Hamden, Connecticut, in cooperation with Yale University

Morgantown, West Virginia, in cooperation with West Virginia University

Orono, Maine, in cooperation with the University of Maine

Parsons, West Virginia

Princeton, West Virginia

Syracuse, New York, in cooperation with the State University of New York, College of Environmental Sciences and Forestry at Syracuse University

University Park, Pennsylvania, in cooperation with The Pennsylvania State University

Warren, Pennsylvania

The United States Department of Agriculture (USDA) Forest Service is a diverse organization committed to equal opportunity in employment and program delivery. USDA prohibits discrimination on the basis of race, color, national origin, sex, religion, age, disability, political affiliation, and familial status. Persons believing that they have been discriminated against should contact the Secretary, U.S. Department of Agriculture, Washington, DC 20250, or call 202-720-7327 (voice), or 202-720-1127 (TTY). 